\title{
Mass mortalities of Pacific oysters Crassostrea gigas reflect infectious diseases and vary with farming practices in the Mediterranean Thau lagoon, France
}

\author{
Fabrice Pernet ${ }^{1, *}$, Jean Barret ${ }^{1}$, Patrik Le Gall ${ }^{1}$, Charlotte Corporeau ${ }^{2}$, \\ Lionel Dégremont ${ }^{3}$, Franck Lagarde ${ }^{1}$, Jean-François Pépin ${ }^{3}$, Nicolas Keck ${ }^{4}$ \\ ${ }^{1}$ Ifremer-Laboratoire Environnement Ressource du Languedoc Roussillon, 34203 Sète, France \\ ${ }^{2}$ Ifremer-UMR LEMAR-Technopole de Brest-Iroise, BP 70, 29280 Plouzané, France \\ ${ }^{3}$ Ifremer-Laboratoire de Génétique et Pathologie, 17390 La Tremblade, France \\ ${ }^{4}$ Laboratoire Départemental Vétérinaire, Conseil Général de l'Hérault, 306 Rue Croix de Las Cazes, CS 6013, 34967 Montpellier \\ Cedex 2, France
}

\begin{abstract}
Experiments were conducted to investigate the effects of farming sites, seeding date, age of oysters, ploidy level and rearing structures on mortality, pathogens and energetic reserves of oysters Crassostrea gigas. Mortality of oysters coincided with infections involving, primarily, the ostreid herpesvirus OsHV-1 and, secondarily, bacteria of the group Vibrio splendidus, when seawater temperature was between 17 and $24^{\circ} \mathrm{C}$. Mortality started in early May and lasted until late September, with an interruption in July and August when seawater temperatures rose above $24^{\circ} \mathrm{C}$. Mortality varied with farming site: oysters maintained in the open Mediterranean Sea showed no mortality and OsHV-1 was occasionally detected at a low level only, while oysters maintained in the farming area of the Thau lagoon exhibited mass mortality events concomitantly with outbreaks of OsHV-1. Mortality of oysters maintained in the Thau lagoon but outside the oyster farming area was sporadic and coincided with currents coming from the farming area where mortality was occurring. Mortality of oysters also varied with farming practices. Naïve oysters remained susceptible to pathogen-related mortality pressure during their first $2 \mathrm{yr}$, whereas oysters that had survived a mass mortality event in the past appeared resistant. Mortalities of diploid (2n) and triploid (3n) oysters were similar during spring but mortalities of $2 \mathrm{n}$ oysters were double those of $3 \mathrm{n}$ oysters during summer and autumn. Finally, oysters grown in Australian baskets suffered $80 \%$ mortality compared with only $30 \%$ among oysters cemented onto ropes. The effects of farming practices on mortality are discussed in relation to pathogens and energetic reserves of oysters.
\end{abstract}

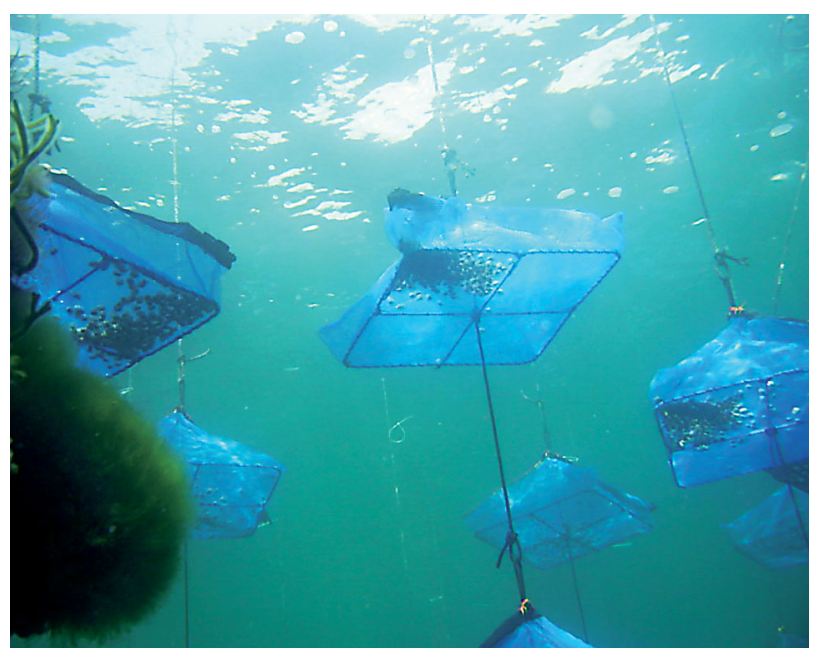

In the Mediterranean area, oyster seed is grown in pearlnets suspended from culture trestles.

Photo: Patrik Le Gall

KEY WORDS: Pacific oyster - Mortality · Disease · Farming practices $\cdot$ Hydrodynamics $\cdot$ Energetic

Resale or republication not permitted without written consent of the publisher

\section{INTRODUCTION}

Since the mid-1970s, large-scale episodic events such as disease epidemics, mass mortalities, and harmful algal blooms and other population explosions have been occurring in marine environments at a historically unprecedented rate (Harvell et al. 1999, 
2002, Lafferty et al. 2004, Mydlarz et al. 2006). Ecologically and economically important invertebrates have been affected by large-scale mass mortalities, generally related to infectious diseases (Mydlarz et al. 2006). In aquaculture species, numerous diseases have emerged through pathogen exchange with wild populations, evolution of pathogenic from nonpathogenic microorganisms and anthropogenic transfer of stocks (Murray \& Peeler 2005, Peeler \& Taylor 2011). Characteristics of the aquaculture environment, such as hydrodynamic connectivity, mixing of waters and close proximity, exacerbate disease epidemics (McCallum et al. 2004, Gustafson et al. 2007, Viljugrein et al. 2009, Salama \& Murray 2011).

During the springs and summers of 2008 and 2009, mass mortalities of 1-yr-old Crassostrea gigas occurred along all coasts of France when seawater temperature reached 16 to $17^{\circ} \mathrm{C}$ (Bédier 2010). These mortality events represented the most serious ecological crisis ever to the French oyster production industry. One-yr-old oysters were decimated at levels ranging from 40 to $100 \%$, depending on locations and batches, whereas older oysters were generally much less affected. For example, 10-mo-old oysters reared in the Thau lagoon (French Mediterranean coast) suffered $85 \%$ mortality during the springsummer period of 2008, irrespective of their origins and ploidy levels (Pernet et al. 2010). Similarly, 7 mo-old oysters deployed in Marennes-Oléron Bay (French Atlantic coast) in August 2009 showed 50\% mortality after only 17 d (Dégremont 2011). Although oyster mortalities were mostly reported in France during this period, there were also several cases in Ireland and the Channel Islands (Lynch et al. 2011, Martenot et al. 2011), and there have been cases more recently in Australia and New Zealand (B. Zippel and H. Kaspar pers. comm.).

Oysters sampled during mortality outbreaks in 2008 showed an elevated prevalence of the ostreid herpesvirus OsHV-1 compared with previous years (Segarra et al. 2010). These authors characterised a genotype of OsHV-1 not previously reported, which was termed OsHV-1 $\mu$ Var. The OsHV-1 $\mu$ Var genotype was only detected in 2008 isolates, suggesting that it is an emergent genotype (Segarra et al. 2010). In addition to this epidemiological work, experimental trials have shown a causal relationship between infection with herpesvirus OsHV-1 $\mu$ Var and oyster mortality (Schikorski et al. 2011a,b). The latter authors showed that both intramuscular injections of viral suspensions prepared from naturally infected oysters and cohabitation assays between healthy and infected oysters could induce up to $80 \%$ mortality within $3 \mathrm{~d}$ in healthy 1 -yr-old oysters. Alongside the herpesvirus, Vibrio spp. are present as ubiquitous marine bacteria and are also frequently associated with severe mortalities in Crassostrea gigas in the field (Saulnier et al. 2010). More particularly, some bacterial isolates related to $V$. splendidus and $V$. aestuarianus induced mortality in healthy oysters under experimental conditions (Garnier et al. 2007, De Decker et al. 2011). A recent field experiment suggested that both herpesvirus OsHV-1 and, to a lesser extent, V. splendidus, could be involved in oyster mass mortality (Dégremont 2011).

The effects of farming practices on oyster mortality have been poorly investigated in the past. Indeed, during the Morest programme (an Ifremer multidisciplinary research programme which aimed at investigating 'summer mortality' in adult oysters in France between 2001 and 2006), mortality was investigated as a function of the 'shellfish farming ecosystem', a generic term encompassing temperature, rainfall, primary productivity and distance from the sediment (Samain \& McCombie 2008). However, several studies of finfish (Murray \& Peeler 2005, Krkošek 2010) and crustaceans (Lightner 2011) have suggested that aquaculture practices may play a role in disease management and mortality.

Although mass mortality phenomena are often related to infectious diseases, they can also reflect an unfavourable energetic balance. Oyster mortalities recorded between 2001 and 2006 occurred when seawater temperatures exceeded $19^{\circ} \mathrm{C}$ during the summer, which is also the time of year when oyster energetic resources are lowest and energy demand and reproductive effort are highest (Soletchnik et al. 1997, Berthelin et al. 2000, Delaporte et al. 2006, Soletchnik et al. 2006, Samain \& McCombie 2008). In 2008, 1-yr-old oysters sampled in the Thau lagoon showed a sharp decrease in carbohydrate concentration and arrested accumulation of lipid reserves before the mortalities occurred (Pernet et al. 2010). It is therefore likely that young oysters go through a phase of energetic weakness during the spring, which renders them more susceptible to pathogen infections. In the same way, it is also possible that oysters with high energetic reserves of, for example, lipids and carbohydrates, are more resistant to pathogen infections than those with low levels.

In France, oyster seed originates from natural collection along the Atlantic coast on spat collectors or from hatcheries and nurseries. Grow-out is entirely sea-based and uses bottom, off-bottom and suspended culture methods. In the Mediterranean area, 
small seed is generally put in mesh bags, whereas larger oysters are held in cages or cemented onto vertical ropes which are then suspended above the bottom from culture tables (Barnabé \& Doumenge 2001, Gangnery 2003, Laing 2009). In coastal lagoons, oyster seed is deployed during spring or autumn and reaches marketable size during the first year. Seed is either diploid (2n) or triploid (3n). Triploid oysters are preferred over diploid ones because they often show faster growth, better survival and a much smaller gonad development compared with their diploid counterparts (e.g. Nell 2002; for review, Normand et al. 2009). Although, in the past, 3n Crassostrea gigas usually showed higher resistance to summer mortality than 2n individuals (Normand et al. 2008, Samain \& McCombie 2008), mortality recorded in the Thau lagoon in 2008 was similar in $2 \mathrm{n}$ and $3 \mathrm{n}$ oysters (Pernet et al. 2010).

The first objective of the present study was to examine the effect of farming practices on oyster mortality. A set of 4 experiments was designed to investigate the effects of farming site, seeding date, oyster age, ploidy level, rearing structures and prior exposure to a mortality event, on mortality. These experiments allowed periods of mortality to be determined in relation to seawater temperature, and the susceptibility of oysters to the mass mortality pressure to be studied in relation to their age.

The second objective was to investigate the relationship between oyster mortality and pathogens in relation to farming practices. Although epidemiological and laboratory studies had strongly suggested that herpesvirus OsHV-1 $\mu$ Var is associated with oyster mortality, the correlation remained to be demonstrated in the field. The role of bacteria such as Vibrio splendidus and V. aesturianus also required clarification. Additionally, the effects of farming practices on the transmission of herpesvirus and Vibrio spp. to Crassostrea gigas were unknown and required further investigation.

The third objective was to investigate the potential contribution of oyster energetic status to explaining oyster mortality and pathogen infection, in relation to farming practices. We hypothesised that farming practices influenced the energetic reserves of oysters, which could then affect their capacity to withstand pathogen infections and thus their mortality rates.

\section{MATERIALS AND METHODS}

\section{Study site}

The Thau lagoon on the French Mediterranean coast is an oyster farming area that accounts for $\sim 10 \%$ of French Pacific oyster Crassostrea gigas production. Oyster growth rates in the lagoon are among the highest in France for this species (Gangnery et al. 2003). The lagoon is $19 \mathrm{~km}$ long, $4.5 \mathrm{~km}$ wide and $5 \mathrm{~m}$ deep on average (Fig. 1). Shellfish are cultured in 3 areas of the lagoon, namely Bouzigues, Mèze and Marseillan, covering about $20 \%$ of the total surface. The lagoon is almost closed off from the Mediterranean Sea, with only narrow connections through the Sète channel, other connections being negligible in terms of water exchange. We conducted our experiments at Marseillan, both inside and outside of the bivalve farming area of the lagoon, and in the open Mediterranean Sea within a mussel farming area (Fig. 1).

\section{Temperature monitoring}

Temperatures were recorded every 10 min over a period of 2.5 yr starting in March 2009, using autonomous CTD multiparameter recorders (NKE Instrumentation) deployed at 2 experimental sites: (1) Mar-

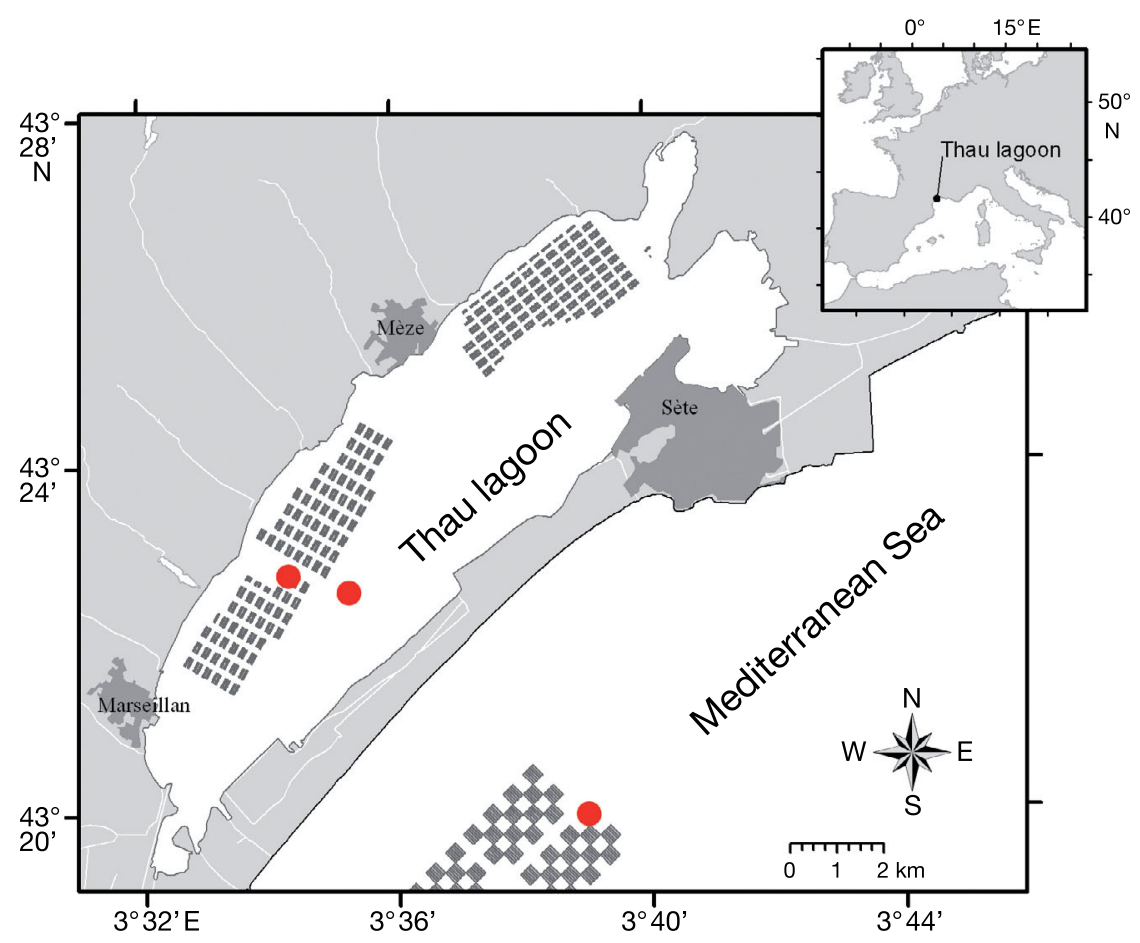

Fig. 1. Sampling sites (red circles) located in the Thau lagoon and in the open Mediterranean sea. Areas with grey boxes: bivalve farms 
seillan within the bivalve farming area of the Thau lagoon and (2) in the open Mediterranean Sea (Fig. 1).

\section{Experimental design}

Expt 1: Seeding date and age of oysters

This experiment was designed to detect whether oysters acquire resistance to mortality as they age and develop. The data collected allowed us to define periods of mortality in relation to pathogens and seawater temperature.
Triploid oysters, purchased from a French commercial hatchery, were used for this study. These oysters had been produced in August 2008 and were deployed in the Thau lagoon on 12 March 2009 and at the open sea experimental site on 18 March 2009. Mean shell length (SL $\pm \mathrm{SD}$ ) was $14 \pm 2 \mathrm{~mm}$ and age of oysters was 8 mo (Table 1). Up until this time, the oysters had shown no mortality. Subsamples of the oysters maintained in the open Mediterranean Sea were then transferred to the bivalve farming area of the Thau lagoon on 7 successive dates. Seeding (transfer) dates, SL and oyster ages are shown in Table 1. Oysters transferred to the Thau lagoon on

Table 1. Summary of experimental designs. NA: not applicable; ind.: individual; nd: not determined; M: Mortality; P: Pathogen, E: Energetic

\begin{tabular}{|c|c|c|c|c|c|c|c|c|}
\hline $\begin{array}{l}\text { Seeding } \\
\text { date to } \\
\text { Thau lagoon }\end{array}$ & $\begin{array}{l}\text { Treat- } \\
\text { ment }\end{array}$ & $\begin{array}{l}\text { Shell length } \\
\text { (in } \mathrm{mm} \pm \mathrm{SD} \text { ) }\end{array}$ & $\begin{array}{l}\text { Age } \\
(\mathrm{mo})\end{array}$ & $\begin{array}{l}\text { Rearing } \\
\text { structure } \\
\text { (and no.) }\end{array}$ & $\begin{array}{l}\text { Density } \\
\text { (no. ind. } \\
\text { per rearing } \\
\text { structure) }\end{array}$ & $\begin{array}{l}\text { No. ind } \\
\text { analysed per } \\
\text { replicate } \\
\text { structure }\end{array}$ & $\begin{array}{l}\text { Type of } \\
\text { analysis }\end{array}$ & $\begin{array}{l}\text { Collection } \\
\text { date for } \\
\mathrm{P} \text { and } \mathrm{E} \\
\text { analyses }^{\mathrm{a}}\end{array}$ \\
\hline \multicolumn{9}{|c|}{ Expt 1: Seeding date and age of oysters - Triploid oysters were produced in August 2008 and deployed 8 times in Thau lagoon } \\
\hline 12 Mar 2009 & NA & $14 \pm 2$ & 8 & Pearlnet $(\mathrm{n}=3$ ) & 250 & 4 (pool) & M. P & 27 Apr, 11 May 2009 \\
\hline 29 May 2009 & NA & $31 \pm 4$ & 10 & Pearlnet $(\mathrm{n}=3)$ & 250 & $4(\mathrm{pool})$ & $\mathrm{M}, \mathrm{P}$ & 29 May, 4, 10, 17 Jun 2009 \\
\hline 19 Oct 2009 & NA & $52 \pm 10$ & 16 & Basket $(\mathrm{n}=3)$ & 100 & 1 (ind.) & M, P & 8, 28 Apr, 5 May 2010 \\
\hline 08 Apr 2010 & NA & $69 \pm 17$ & 20 & Basket (n = 3) & 100 & 1 (ind.) & $\mathrm{M}, \mathrm{P}$ & 28 Apr, 5 May 2010 \\
\hline 27 May 2010 & NA & $78 \pm 12$ & 22 & Basket (n = 3) & 100 & 3 (ind.) & M, P & 27 May, 4, 7 and 11 Jun 2010 \\
\hline 23 Jun 2010 & NA & Unchanged & 23 & Basket ( $\mathrm{n}=3$ ) & 100 & 3 (ind.) & M, P & 15 Jul, 12 17, 19, 23 Aug 2010 \\
\hline 17 Sep 2010 & NA & Unchanged & 26 & Basket (n=3) & 100 & 3 (ind.) & $\mathrm{M}, \mathrm{P}$ & 30 Sept 2010 \\
\hline 10 Jan 2011 & NA & Unchanged & 30 & Basket $(\mathrm{n}=3)$ & 100 & Not sampled & $\mathrm{M}$ & nd \\
\hline \multicolumn{9}{|c|}{ Expt 2: Seeding date and ploidy level - Diploid and triploid oysters were produced in August 2009 and deployed 4 times in Thau lagoon } \\
\hline 12 Mar 2010 & $\begin{array}{l}2 n \\
3 n\end{array}$ & $\begin{array}{l}15 \pm 3 \\
16 \pm 3\end{array}$ & 8 & Pearlnet $(\mathrm{n}=4)$ & 250 & 6 (pooled) & $\mathrm{M}, \mathrm{P}$ & 15, 26, 29 Apr 2010 \\
\hline 27 May 2010 & $\begin{array}{l}2 n \\
3 n\end{array}$ & $\begin{array}{l}32 \pm 6 \\
37 \pm 8\end{array}$ & 10 & Pearlnet $(\mathrm{n}=3)$ & 100 & Not sampled & M & nd \\
\hline 23 Jun 2010 & $\begin{array}{l}2 n \\
3 n\end{array}$ & $\begin{array}{l}37 \pm 6 \\
46 \pm 6\end{array}$ & 11 & Basket $(\mathrm{n}=2)$ & 100 & 6 (pooled) & $\mathrm{M}, \mathrm{P}$ & 15 Jul, 12, 17, 19, 23 Aug 2010 \\
\hline 17 Sep 2010 & $\begin{array}{l}2 n \\
3 n\end{array}$ & $\begin{array}{l}37 \pm 6 \\
46 \pm 8\end{array}$ & 14 & Basket $(n=3)$ & 100 & 3 (ind.) & $\mathrm{M}, \mathrm{P}$ & 30 Sep 2010 \\
\hline \multicolumn{9}{|c|}{$\begin{array}{l}\text { Expt 3: Rearing structure and sites - Triploid oysters in Expt } 1 \text { transferred on } 27 \text { May } 2010 \text { in Thau lagoon were used for this experiment. } \\
\text { Oysters were transferred inside or outside the farming area (treatment) }\end{array}$} \\
\hline 27 May 2010 & $\begin{array}{l}\text { Inside } \\
\text { Inside }\end{array}$ & $78 \pm 12$ & 22 & $\begin{array}{l}\text { Basket }(\mathrm{n}=3) \\
\text { Rope }(\mathrm{n}=6)\end{array}$ & $\begin{array}{c}100 \\
60\end{array}$ & $\begin{array}{c}3 \text { (ind.) } \\
3 \text { (ind. sampled } \\
\text { on } 3 \text { ropes only) }\end{array}$ & $M, P, E^{b}$ & $\begin{array}{c}4,7 \text { and } 11 \text { Jun } 2010 \\
4,7 \text { and } 11 \text { Jun, 15 Jul, } \\
1217,19,23 \text { Auq } 2010\end{array}$ \\
\hline & Outside & & & Basket $(n=3)$ & 100 & 3 (ind.) & & 4,7 and 11 Jun 2010 \\
\hline $\begin{array}{l}23 \text { Jun } 2010 \\
\text { (replacement) }^{\mathrm{c}}\end{array}$ & Inside & Unchanged & 23 & Basket $(n=3)$ & 100 & 3 (ind.) & $\mathrm{M}, \mathrm{P}$ & 15 Jul, 12 17, 19, 23 Aug 2010 \\
\hline $\begin{array}{l}17 \text { Sep } 2010 \\
\text { (replacement) }^{\mathrm{c}}\end{array}$ & $\begin{array}{l}\text { Inside } \\
\text { Outside }\end{array}$ & Unchanged & 26 & Basket $(\mathrm{n}=3)$ & 100 & 3 (ind.) & $\mathrm{M}, \mathrm{P}$ & 30 Sept 2010 \\
\hline \multicolumn{9}{|c|}{ Expt 4: Previous exposure to mortality - Diploid and triploid oysters in Expt 2 were used for this experiment } \\
\hline $\begin{array}{l}23 \text { June } 2010^{\mathrm{d}} \\
\left(t_{0}: 10 \text { Jan } 2011\right) \\
10 \text { Jan } 2011\end{array}$ & $\begin{array}{c}\text { Exposed } 2 n \\
\text { Exposed 3n } \\
\text { Naïve } 2 n \\
\text { Naïve } 3 n\end{array}$ & $\begin{array}{c}55 \pm 7 \\
74 \pm 10 \\
70 \pm 12 \\
70 \pm 14\end{array}$ & 17 & Basket $(\mathrm{n}=1)$ & 60 & Not sampled & M & nd \\
\hline \multicolumn{9}{|c|}{$\begin{array}{l}\text { cReplacement of missing experimental units due to low abundance of oysters after severe mortality } \\
\text { dOYysters were transferred on } 23 \text { June } 2010 \text { to the Thau lagoon, but experimental units (baskets) used in Expt } 4 \text { were constituted } 4 \text { Jan } \\
2011 \text { only. Remaining oysters ( } 2 \mathrm{n} \text { and } 3 \mathrm{n} \text { ) from Expt } 2 \text { exposed to the mortality event during summer } 2010 \text { were pooled into } 1 \text { basket for } \\
\text { each ploidy level due to low abundance after severe mortality }\end{array}$} \\
\hline
\end{tabular}


12 March (initial seeding) and 29 May 2009 (subsample transferred from open sea site) were maintained in 3 pearlnets at an initial density of 250 individuals per net. Oysters transferred thereafter were maintained in 3 Australian baskets (BST oyster supplies) at an initial density of 100 individuals per basket (Table 1).

Oyster mortality and pathogens were studied in relation to seeding date and time after transfer to the Thau lagoon. It should be noted that seeding date, age and size of oysters were confounded. Detection of pathogens in oysters transferred on 12 March and 29 May 2009 was performed on 4 pooled oysters for each pearlnet $(\mathrm{n}=2$ or 3 pearlnets, giving 8 or 12 individuals in all). For the later dates, pathogen analyses were conducted on individual oysters. For oysters transferred on 19 October 2009 and 8 April 2010, only one oyster per Australian basket was analysed $(\mathrm{n}=3$ individuals). From 27 May 2010 onwards, 3 oysters per Australian basket were individually analysed ( $\mathrm{n}=$ 9 individuals). All analyses were performed on living oysters.

Expt 2: Seeding date and ploidy level

The objective of this experiment was to test whether the interaction of seeding date and ploidy level had significant effects on mortality, in relation to pathogens and energetic reserves. For this experiment, diploid (2n) and triploid (3n) oysters were produced at the Ifremer hatchery in La Tremblade in August 2009 and then maintained in the nursery at the Ifremer marine station in Bouin from October 2009. There were no mortalities among this population before oysters were deployed in the Thau lagoon on 12 March 2010 and at the open sea experimental site on 18 March 2010. Mean SL and age of 2n and 3n oysters are shown in Table 1.

Subsamples of the oysters maintained in the open sea were then transferred to the bivalve farming area of the Thau lagoon on 3 successive dates. See Table 1 for seeding (transfer) dates, SL and ages of $2 n$ and $3 n$ oysters.

When the batches of $2 \mathrm{n}$ and $3 \mathrm{n}$ oysters were transferred from the open sea experimental site to the Thau lagoon, they were placed in 3 Australian baskets per batch, at an initial density of 100 individuals per basket (Table 1). Mortality of oysters and presence of pathogens were monitored according to seeding date and time after transfer to the Thau lagoon. As in Expt 1, seeding date, age and size of oysters were confounded. Pathogen analyses on oysters transferred on 12 March and 23 June were conducted on 6 pooled individuals sampled from each basket ( $\mathrm{n}=2$ to 4 baskets). Oysters were collected on 15, 26 and 29 April for oysters transferred on 12 March, and 15 July, 12, 17, 19 and 23 August for those transferred on 23 June. For oysters transferred on 17 September, 3 oysters per Australian basket collected on 30 September were analysed individually ( $\mathrm{n}=9$ individuals). All analyses were performed on living oysters.

\section{Expt 3: Rearing structures and sites}

The first objective of this experiment was to examine the effect of the 2 main oyster-rearing structures used in the Thau lagoon on mortality, pathogens and energetic reserves. For this experiment, we used triploid oysters purchased from a commercial hatchery, transferred to the Thau lagoon on 27 May 2010 $(\mathrm{SL}=80 \pm 12 \mathrm{~mm}$ [mean $\pm \mathrm{SD}]$, age $=22 \mathrm{mo}$; see 'Expt 1: Seeding date and age of oysters', above). These oysters were either maintained in 3 Australian baskets as previously described, or cemented onto six $2.5 \mathrm{~m}$ long ropes (Table 1). Twenty groups of 3 oysters were evenly spaced along the length of each rope (Gangnery 2003). Density of oysters in Australian baskets was at least 6 times higher than that of oysters cemented to ropes. Therefore, rearing structures and density are confounded. Three ropes were used specifically for studies on pathogen detection and energetic reserves, whereas the 3 other ropes were used for mortality counts. These animals were deployed within the oyster farming area of Marseillan.

The second objective of this experiment was to look at the effect of closeness to the farming area on oyster mortality, pathogens and energetic reserves. For each batch, 3 Australian baskets containing 100 oysters each were deployed within the Thau lagoon but outside of the farming area of Marseillan (Fig. 1), allowing a comparison between the oysters that were grown within the main farming area with those grown outside of it.

As high mortality occurred in oysters maintained in Australian baskets, further transfers of triploid oysters were made from the open Mediterranean Sea on 23 June and 17 September 2010. These additional transfers allowed the continuation of mortality comparisons between oysters deployed inside and outside of the farmed area.

Mortality of oysters and presence of pathogens were monitored according to seeding date and time after transfer to the Thau lagoon. As in Expts 1 and 
2, seeding date, age and size of oysters were confounded. On 4 June 2010, when differences in survival between treatments were observed, energetic analyses were carried out. Pathogen analyses were conducted on 3 individual oysters per Australian basket or rope ( $\mathrm{n}=9$ individuals per treatment). Oysters were sampled on 27 May, 4 June, 7 June, 11 June, 15 July, 12 August, 17 August, 19 August, 23 August and 30 September 2010 (Table 1). All analyses were performed on living oysters.

In order to examine the hydrodynamic connectivity between the sites located inside and outside of the oyster farming area, current velocity and direction were measured using a tri-dimensional acoustic Doppler velocimeter (3D-ADCP, RDI-Teledyne). The 3D-ADCP was placed below the experimental oyster farming table, anchored to the bottom and set up to measure current velocity and direction at every centimetre of the entire water column.

\section{Expt 4: Previous exposure to mortality}

The objective of this experiment was to investigate whether mortality of oysters is influenced by previous exposure to a mortality event. Mortalities of $2 \mathrm{n}$ and $3 \mathrm{n}$ oysters transferred to the Thau lagoon on 23 June 2010, which thereafter suffered heavy losses in August of the same year (Expt 2, 'exposed groups'), were compared with oysters from the same batches that had been maintained in an area free of mortality in the open Mediterranean Sea until their transfer to the Thau lagoon on 10 January 2011 ('unexposed groups', also referred to as 'naïve').

All oysters were held in Australian baskets at an initial density of 60 oysters per basket (Table 1). Oysters that had been exposed to the mortality event in 2010 were maintained in only one basket for each ploidy level. The number of oysters that survived the 2010 mortality event was too low to have several Australian baskets per ploidy level. Naïve $2 \mathrm{n}$ and $3 \mathrm{n}$ oysters were kept in 2 Australian baskets per ploidy level.

\section{Variables}

Mortality

Live and dead oysters were counted in each experimental unit (pearlnet, basket or rope) to determine cumulative mortality, which was expressed as a probability. Dead oysters were removed. Cumulative mortality was calculated as follows:

$$
P_{\text {cum }(t-1)}=\left(1-P_{\text {inst }(t)}\right) \times P_{\text {cum }(t-1)}+P_{\text {inst }(t)}
$$

where $P_{\operatorname{cum}(t)}$ is the probability of cumulative mortality at time $t$ and $P_{\text {inst }(t)}$ is the probability of instantaneous mortality at time $t$, which is:

$$
P_{\text {inst(t) }}=\frac{\text { nb.dead }_{(t)}}{\text { nb.dead }_{(t)}+\text { nb.alive }_{(t)}}
$$

where nb. is number. $P_{\text {cum }(t-1)}$ is the probability of cumulative mortality at time $t-1$ (previous sampling time). The latter formula allows the oysters sampled for pathogen detection and energetic reserve analyses to be taken into account.

\section{Biometry}

Oysters were sampled for shell length and tissue dry mass at the beginning of each experiment and at seeding in the Thau lagoon. Shell length, defined as the greatest anteroposterior length, was measured with a digital calliper (Mitutoyo) on a subsample of 25 oysters from each pearlnet and Australian basket. Dry masses were measured on 3 pooled individuals for small 1-yr-old oysters. For larger 2-yr-old oysters, dry masses were measured individually on 3 oysters per experimental unit. Tissues for dry mass measurements were placed in pre-weighed aluminium cups, dried for $72 \mathrm{~h}$ at $60^{\circ} \mathrm{C}$ and weighed on a Mettler precision balance (Mettler-Toledo).

\section{Pathogens and energetic parameters}

Whole oyster tissues were dipped into liquid nitrogen immediately after sampling and then stored at $-80^{\circ} \mathrm{C}$. Individual specimens or pooled oysters were ground with a MM400 homogeniser (Retsch) and the resulting powders stored at $-80^{\circ} \mathrm{C}$ and subsampled for pathogen detection and biochemical analyses.

\section{Pathology}

DNA extraction

A subsample of oyster tissues (50 to $100 \mathrm{mg}$ of fine powder) was diluted in artificial seawater $(1: 4, \mathrm{~m} / \mathrm{v})$. Total DNA was then extracted using a Qiagen QIAamp tissue mini kit according to the manufacturer's protocol. The extracted DNA was stored at $-20^{\circ} \mathrm{C}$ prior to pathogen detection and quantification by quantitative PCR (qPCR). 


\section{DNA quantification of herpesvirus OsHV-1}

The detection and quantification of OsHV-1 DNA was carried out using a previously published realtime PCR protocol (Pepin et al. 2008). Briefly, this protocol used SYBR ${ }^{\circledR}$ Green chemistry with specific DPFor/DPRev primers targeting the region of the OsHV-1 genome predicted to encode a DNA polymerase catalytic subunit (Webb et al. 2007). Amplification reactions were performed using an Mx30005P real-time PCR thermocycler sequence detector (Stratagene) with 96-microwell plates, according to the conditions described by Pepin et al. (2008). Results were expressed as viral DNA copy number $\mathrm{mg}^{-1}$ wet tissue. Based on data observed in 2009 and 2010 by the French network on mollusk pathology of the Ifremer (REseau PAthologie des MOllusques, REPAMO, 2009, 2010) it can be argued that viral DNA detected in our study is essentially the genotype OsHV-1 $\mu$ Var.

\section{DNA quantification of Vibrio splendidus and $V$. aestuarianus}

The detection and quantification of Vibrio splendidus and $V$. aestuarianus DNA was carried out using a previously published real-time PCR protocol (Saulnier et al. 2009). The method was adapted for direct detection of bacterial DNA from whole DNA extracted from oyster tissue. This method consists of qPCR multiplex DNA amplification of bacterial colonies with primers and a Taqman probe (SpF/SpR and Spprobe for $V$. splendidus; DNAjaesF1/DNAjaesR1 and DNAj probe for V. aestuarianus). All bacterial colonies belonging to the polyphyletic group of $V$. splendidus are specifically detected. This group is currently represented by 8 species: $V$. lentus, $V$. cyclitrophicus, V. pomeroyi, V. tasmaniensis, V. splendidus, V. kanaloae, V. gigantis and V. crassostreae. Similarly, all bacterial colonies belonging to $V$. aestuarianus were specifically detected. The results were expressed as bacterial colony forming unit (CFU) number $\mathrm{mg}^{-1}$ wet tissue.

\section{Energetic parameters}

$$
\text { Carbohydrates }
$$

Samples of 100 to $200 \mathrm{mg}$ of fine powder were placed in Eppendorf tubes containing $1.5 \mathrm{ml}$ nanopure water, homogenised for $\sim 30 \mathrm{~s}$ on ice with a T10 basic ultra Turrax (IKA) and diluted 2.5, 5.0 or 10.0 times according to carbohydrate concentration. A subsample of the diluted powder $(250 \mu \mathrm{l})$ was mixed with $500 \mu \mathrm{l}$ phenol solution $(5 \% \mathrm{~m} / \mathrm{v})$ and $2.5 \mathrm{ml}$ $\mathrm{H}_{2} \mathrm{SO}_{4}$ and incubated for 20 min (DuBois et al. 1956). The subsample was then placed in a double-beam UV-visible spectrophotometer (UVmc2 SAFAS) and absorbance measured at $490 \mathrm{~nm}$ and $600 \mathrm{~nm}$. Optical density (OD) was calculated according to the following formula:

$$
\mathrm{OD}=\mathrm{OD}_{490 \mathrm{~nm}}-1.5 \times\left(\mathrm{OD}_{600}-0.003\right)
$$

Total carbohydrate concentration was then calculated using a standard calibration curve and expressed in $\mathrm{mg} \mathrm{g}^{-1}$ dry mass of tissues.

\section{Lipids}

Powder aliquots (150 mg) were placed in amber glass vials filled with $3 \mathrm{ml}$ chloroform-methanol (2:1, v/v) for further extraction following Folch et al. (1957). Extracts were concentrated to $0.4 \mathrm{ml}$, and $4 \mu \mathrm{L}$ of each was applied to SIII Chromarods (Iatron laboratories) using a $10 \mu$ Hamilton air-tight glass syringe. A short development in acetone was used to concentrate the samples into a narrow band on the Chromarods. After drying the rods, lipid classes were separated in a stepwise procedure using developing solvents of increasing polarity (Parrish 1999). This method separates aliphatic hydrocarbons, sterol and wax esters, ketones, triacylglycerols (TAG), free fatty acids, free fatty alcohols, free sterols, diacylglycerols, acetone mobile polar lipids and phospholipids. Between each development, the Chromarods were partially scanned by flame ionization detection (FID) on an Iatroscan MK-VI (Iatron Laboratories). Chromatograms were analysed using integration software (Peak Simple version 3.29, SRI). Lipid classes were quantified using standard calibration curves obtained for each lipid class. For the purpose of this study, only TAG in whole tissues of oysters are presented.

\section{Enzymes}

Powder samples (200 mg) were placed in Eppendorf tubes filled with $1 \mathrm{ml}$ ice-cold lysis buffer (150 mM NaCl, $10 \mathrm{mM}$ Tris, $1 \mathrm{mM}$ EDTA, $1 \mathrm{mM}$ EGTA, 1\% Triton X-100, 0.5\% Igepal, 2 mM PMSF, $10 \mu \mathrm{g} \mathrm{ml}^{-1}$ leupeptin, $10 \mu \mathrm{g} \mathrm{ml}^{-1}$ aprotinin, $100 \mathrm{mM}$ sodium fluoride, $10 \mathrm{nM}$ sodium pyrophosphate, and 
$2 \mathrm{mM}$ sodium orthovanadate; $\mathrm{pH} 7.4$ ), and proteins were extracted as described by Corporeau et al. (2011). Protein lysates were quantified using a DC protein assay (Bio-Rad) and diluted at the same concentration in ice-cold lysis buffer.

The activity of citrate synthase (CS; EC 4.1.3.7), a key enzyme of energetic metabolism, was assayed using the method of Childress \& Somero (1979). The assay reaction is based on the reaction of 5, 5' -dithiobis(2-nitrobenzoic acid) (DTNB) with the reactive -SH group of the free co-enzyme A. The 2-nitro-5thiobenzoate (NTB) produced is yellow and its maximum absorbance is at $\sim 412 \mathrm{~nm}$.

The activities of hexokinase (HK; EC 2.7.1.1), pyruvate kinase ( $\mathrm{PK} ; \mathrm{EC}$ 2.7.1.40) and phosphoenolpyruvate carboxykinase (PEPCK; EC 4.1.1.32) in oyster tissues were determined as described by Greenway \& Storey (1999). Increase in NADPH or decrease in $\mathrm{NADH}$ were followed by monitoring the absorbance at $340 \mathrm{~nm}$.

All assays were made in duplicate at room temperature and initiated by mixing the enzyme buffer with $20 \mu \mathrm{l}$ homogenate in a $220 \mu \mathrm{l}$ total microplate-well volume. Absorbance was measured using a BioTek microplate reader (BioTek Instrument).

\section{Statistical analyses}

No statistical tests were performed on data collected in Expts 1 and 4. Both mortality and pathogen data were clear and no further statistical analysis was required. In Expts 2 and 3, statistical tests were conducted to test the effects of ploidy level and farming practices (a generic term which include both rearing structures and sites) on mortality, pathogen detection and energetic parameters.

\section{Mortality}

Mortalities in Expts 2 and 3 were analysed for each sampling date using the GENMOD procedure with a logit transformation and a binomial distribution as described by Dégremont (2011). Briefly, the model is:

$$
\operatorname{logit}(Y i)=\log [Y i /(1-Y i)]=\mu+\text { factor } i
$$

where $Y i$ is the probability of mortality for the $i$ th factor, $\mu$ is the intercept, and factor $i$ is the effect of the ith factor. Multiple comparison tests were conducted using the least squares means statement and pdiff option. All survival analyses were conducted using SAS 9.1.3 (SAS Institute).

\section{Pathogens}

As no Vibrio aestuarianus was found in any oyster in this study, data on this pathogen was not included in the statistical analyses performed. Detection frequencies of OsHV-1 and Vibrio splendidus in Expt 3 were analysed by chi-square tests of independence using SAS 9.1.3 (SAS Institute).

Two-way repeated measures analyses of variance (ANOVAs) were used to compare differences in quantities of herpesvirus OsHV-1 and Vibrio splendidus DNA between ploidy levels in Expt 2 and between farming practices in Expt 3 (see Table 2). Three distinct ANOVAs were conducted within each of these experiments. In Expt 2, ANOVAs included the time periods from 15 to 29 April, 15 July to 23 August, and 30 September 2010 only. In Expt 3, ANOVAs included the time periods from 4 to 11 June, 15 July to 19 August, and 17 to 30 September 2010. Mauchly's test was used to assess whether datasets conformed to the sphericity assumption required for a repeated measures analysis. When the sphericity assumption was not met, the degrees of freedom (df) were adjusted accordingly, using the Huynh-Feldt correction. Data were $\log (x+1)$ transformed to achieve normality of residuals and homogeneity of variances. These analyses were carried out using SPSS 15.0.

In Expt 3 and at the end of Expt 2, pathogen analyses were conducted on 3 individual oysters per rearing structure (baskets or ropes). It was therefore possible to run statistics using the variation among individual samples $(\mathrm{n}=9)$ or the variation among replicates $(n=3)$. Although samples are 'pseudoreplicates' (Hurlbert 1984), chi-square tests were conducted using individual measurements to maximise the number of observations for obtaining a valid test. In contrast, ANOVAs were conducted on mean values for each replicated rearing structure (baskets or ropes from which several oysters were taken) to properly reflect the experimental design.

\section{Energetic parameters}

One-way ANOVA was conducted to determine potential differences in energetic parameters of oysters according to farming practices when mortality started on 4 June 2010 in Expt 3 (see Table 3).

Oysters sampled in Expt 3 between 27 May and 7 June 2010 were classified according to their pathological status, irrespective of rearing structures or sites (see Table 4). Oysters were either pathogen 
free, infected by herpesvirus only, infected by Vibrio splendidus only or infected by both herpesvirus and $V$. splendidus. A 1-way ANOVA was then performed to determine differences in energetic parameters of oysters according to their pathological status.

Significant differences between all possible combinations of sample means were assessed using a post hoc Tukey's Honestly Significant Difference test or planned contrasts between group means. TAG data were $\log (x+1)$ transformed to achieve normality of residuals and homogeneity of variances. These analyses were carried out using SPSS 15.0.

\section{RESULTS}

\section{Seeding date and age of oysters (Expt 1)}

$$
\text { Mortality }
$$

Oyster mortality occurred in the Thau lagoon when seawater temperature was between 17 and $24^{\circ} \mathrm{C}$, irrespective of seeding date, age or size (Fig. 2). There was no mortality between October and May, when seawater temperature was $<17^{\circ} \mathrm{C}$, or between 23 June 2010 and 9 August 2010, when seawater temperatures were between 24 and $28^{\circ} \mathrm{C}$.

Cumulative mortality was $79 \pm 11 \%$ (mean \pm SD) over the springs of 2009 and 2010. During summer 2010 , mortality reached only $58 \pm 15 \%$, when seawater temperature was close to $24^{\circ} \mathrm{C}$. Finally, mortality decreased to $18 \pm 14 \%$ and $30 \pm 2 \%$ during autumn 2010 and spring 2011, respectively. Oyster batches that remained in the open sea did not suffer any mortality. Although seawater temperature in the open sea was markedly lower than that in the Thau lagoon, it was still $>17^{\circ} \mathrm{C}$ during the summers of 2009 and 2010 (Fig. 2). Therefore, oysters maintained in the open sea, in an area without mortalities, did not become resistant to the mortality pressures in the Thau lagoon during the first $2 \mathrm{yr}$.

\section{Pathogens}

OsHV-1 detection frequency in oysters maintained in the open sea, away from mortality risks, was only $36 \%$ (10 out of 28 ), and concentrations of viral DNA were 1 or 2 orders of magnitude lower than the threshold value of $10^{4}$ DNA copy number $\mathrm{mg}^{-1}$ wet tissue (Fig. 3A) at which OsHV-1 is considered to be involved in mortality (Oden et al. 2011, Schikorski et al. 2011a). In contrast, detection frequency and quantity of OsHV-1 DNA increased markedly during mortality events, attaining up to between $10^{6}$ and $10^{8}$ DNA copy number $\mathrm{mg}^{-1}$ wet tissue. When mortalities stabilised, detection frequency and quantity of OsHV-1 DNA decreased markedly (Fig. 3A). During autumn 2011, detection frequency and quantity of viral DNA increased only moderately, coinciding with low mortality.

Detection frequency of the polyphyletic Vibrio splendidus bacterial group in oysters maintained in the open sea was $96 \%$ (27 out of 28), and mean concentration was $1.7 \times 10^{4}$ DNA copy number $\mathrm{mg}^{-1}$ wet tissue (Fig. 3B). In oysters acclimated to the Thau lagoon, $V$. splendidus DNA was generally low in quantity or not detected. During the mortality events of April 2009 and 2010, detection frequency and quantity of $V$. splendidus DNA in oyster tissues increased markedly (Fig. 3B). In contrast, V. splendidus remained undetected during the mortalities recorded in June 2009 and August 2010.

\section{Seeding date and ploidy level (Expt 2)}

\section{Mortality}

As observed in Expt 1, mortality of diploid (2n) and triploid (3n) oysters transferred to the Thau lagoon in 2010 occurred when seawater temperature was between 17 and $24^{\circ} \mathrm{C}$ (Fig. 4). There was no mortality

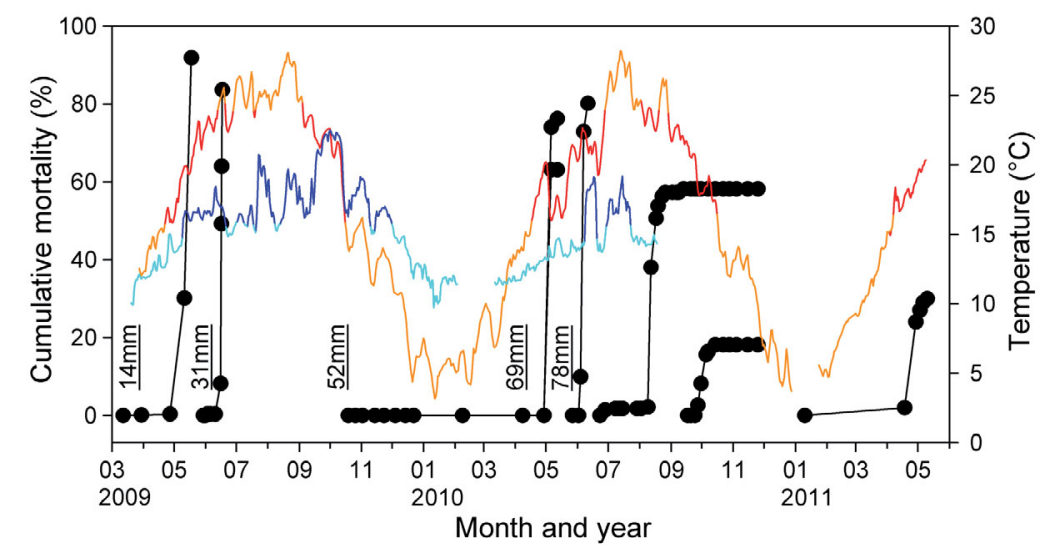

Fig. 2. Crassostrea gigas. Cumulative mortality of oysters in the Thau lagoon according to transfer (seeding) dates from the open sea site to the lagoon (Expt 1), in relation to seawater temperature. Shell lengths measured at transfer are in mm. Oysters continuously reared in the open sea remained free of mortality (data not shown). Red (orange) line: lagoon water temperature between 17 and $24^{\circ} \mathrm{C}\left(<17^{\circ} \mathrm{C}\right.$ or $\left.>24^{\circ} \mathrm{C}\right)$; dark blue (light blue) line: open sea water temperature between 17 and $24^{\circ} \mathrm{C}\left(<17^{\circ} \mathrm{C}\right)$ 

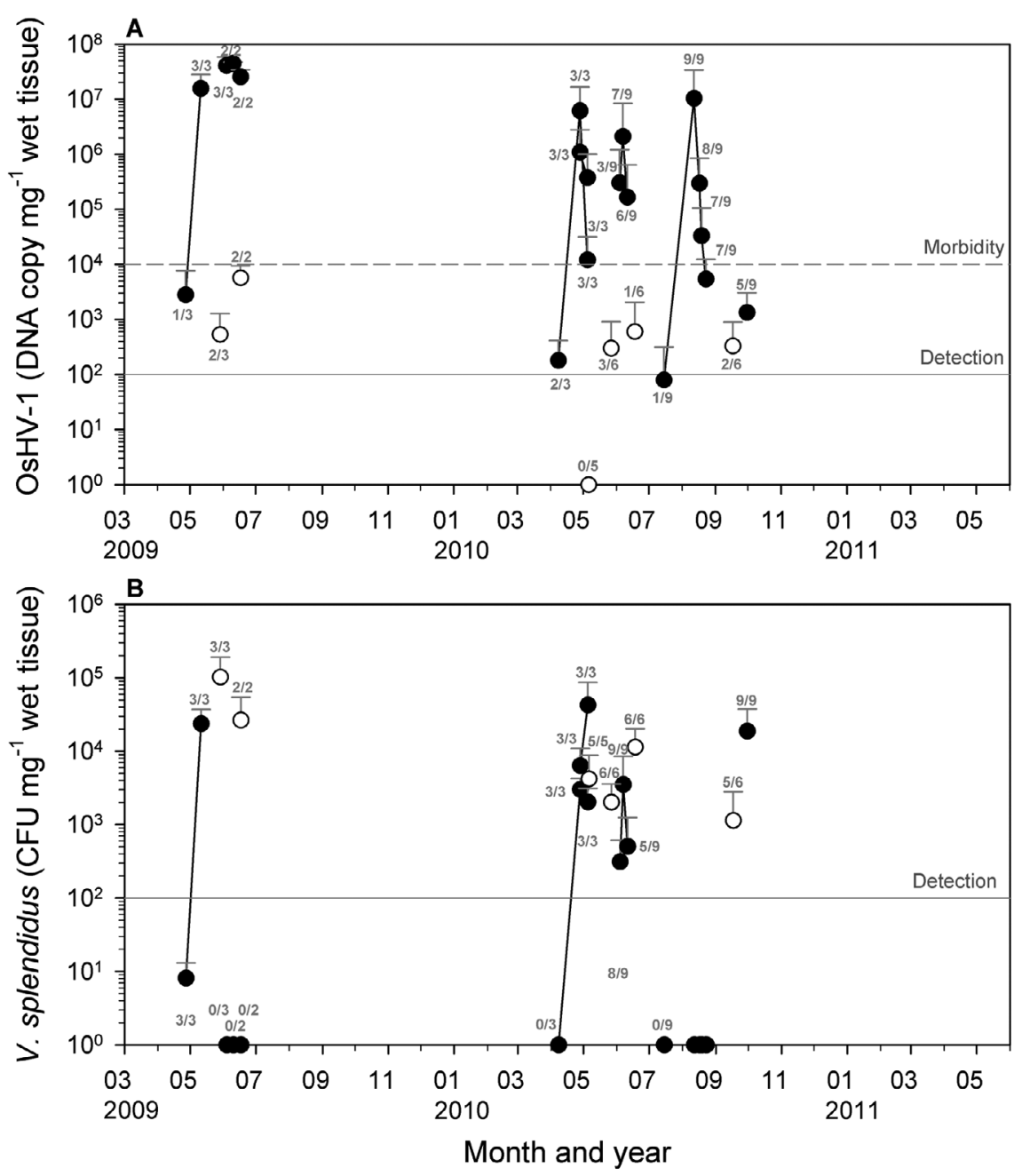

Fig. 3. Crassostrea gigas. Temporal variations in (A) herpesvirus OsHV-1 and (B) Vibrio splendidus abundance (mean $+\mathrm{SD}$ ) in oysters in the Thau lagoon $(\bullet)$, transferred between 12 March 2009 and 17 September 2010 from the open Mediterranean Sea where no mortality occurred (Expt 1). Values for oysters continuously reared in the open sea (O) are given for reference. DNA detection of herpesvirus and $V$. splendidus in transferred oysters was performed on pooled oysters for each pearlnet and individuals per Australian basket (see Table 1 for details of experimental design). Fractions indicate the number of infected individuals, or nets when several individuals were pooled, compared to the total number analysed. Solid lines: pathogen detection thresholds. Dashed line in $(\mathrm{A})$ : threshold above which the herpesvirus is considered to be involved in mortality

between 23 June 2010 and 9 August 2010 when seawater temperature was between 24 and $28^{\circ} \mathrm{C}$.

The interaction of seeding date and ploidy level had an effect on mortality (Fig. 4). Final spring mortalities were similar between $2 \mathrm{n}$ and $3 \mathrm{n}$ oysters $\left(\chi^{2}\right.$ tests, $\mathrm{p}>0.050$ ), but summer and autumn mortalities were higher in $2 \mathrm{n}$ oysters than $3 \mathrm{n}$ oysters. Although $2 \mathrm{n}$ and $3 \mathrm{n}$ oysters transferred to the Thau lagoon on 23 June 2010 died at the same rate between 12 and 19 August 2010 ( $\chi^{2}$ tests, $\left.p>0.500\right)$, on 23 August, mortality of $3 \mathrm{n}$ oysters stabilised at $\sim 26 \%$, while mor- tality in $2 \mathrm{n}$ oysters reached $39 \%\left(\chi^{2}\right.$ test, $\mathrm{p}=0.001$ ). Final mortality of $2 \mathrm{n}$ oysters was 2.3 times higher than that of $3 \mathrm{n}$ oysters $\left(\chi^{2}\right.$ test, $\left.\mathrm{p}<0.001\right)$. Similarly, final mortality of $2 \mathrm{n}$ oysters transferred to Thau lagoon on 17 September 2010 was 1.5 times higher than that of $3 \mathrm{n}$ oysters $\left(\chi^{2}\right.$ test, $\left.\mathrm{p}=0.031\right)$. Overall, spring mortality levels and rates of increase were higher than those occurring during summer and the autumn (Fig. 4), particularly for $3 \mathrm{n}$ oysters.

\section{Pathogens}

OsHV-1 detection frequency in $2 \mathrm{n}$ and $3 \mathrm{n}$ oysters maintained in a mortality-free area in the open sea was $72 \%$ (10 out of 14), which is 2 times higher than that reported in Expt 1. However, as observed in Expt 1, quantity of viral DNA remained lower than the threshold values of $10^{4}$ DNA copy number $\mathrm{mg}^{-1}$ wet tissue at which OsHV-1 is considered to be involved in mortality (Fig. 5A). It is noteworthy that OsHV-1 DNA was not detected in $2 \mathrm{n}$ and $3 \mathrm{n}$ oysters sampled before field deployment $(\mathrm{n}=50$ individuals analysed for each group, data not shown) Also, as observed in Expt 1, the level of OsHV1 DNA increased markedly during mortality events (Table 2), attaining between $10^{6}$ and $10^{8}$ DNA copy number $\mathrm{mg}^{-1}$ wet tissue. When mortalities had stabilised, detection frequency and quantity of OsHV-1 DNA decreased markedly (Fig. 5A, Table 2). In contrast to Expt 1, OsHV-1 detection frequency and quantity also increased during the mortality event in autumn 2010. Ploidy level had no effect on detection of OsHV-1 DNA, irrespective of seeding date (Table 2).

Detection frequency of Vibrio splendidus in $2 \mathrm{n}$ and $3 \mathrm{n}$ oysters maintained in the open sea was $86 \%(12$ out of 14) and mean concentration was $2.2 \times 10^{3}$ DNA copy number $\mathrm{mg}^{-1}$ wet tissue (Fig. 5B). Detection frequency and quantity in $V$. splendidus DNA increased markedly in oyster tissues during the mortality event in April 2010, and to a much lesser extent in September 2010 (Fig. 5B, Table 2). In contrast, V. splendidus remained undetected during the mortalities recorded 
Fig. 4. Crassostrea gigas. Cumulative mortality of diploid (2n) and triploid $(3 n)$ oysters in the Thau lagoon (Expt 2), as a function of transfer (seeding) date from the open Mediterranean Sea where no mortality occurred (data not shown), in relation to lagoon water temperature. Shell lengths measured at transfer are in $\mathrm{mm}$, with values for $2 \mathrm{n}$ oysters given first. Black (grey) line: water temperature between 17 and $24^{\circ} \mathrm{C}\left(<17^{\circ} \mathrm{C}\right.$ or $\left.>24^{\circ} \mathrm{C}\right)$

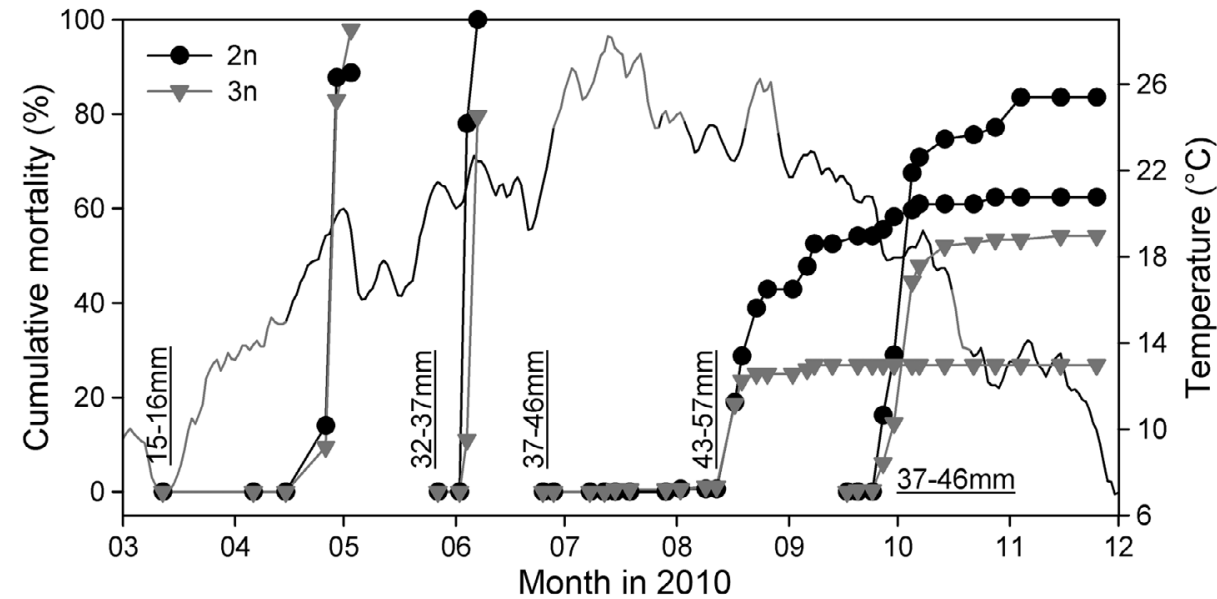

in August 2010, as previously reported for Expt 1. Ploidy level had no effect on quantity of $V$. splendidus DNA, irrespective of seeding date (Table 2).

Rearing structures and sites (Expt 3)

\section{Mortality}

Mortalities in oysters transferred to the farming area ('inside') of Thau lagoon on 27 May 2010 and kept in Australian baskets started on 4 June, at $\sim 10 \%$ and reached $\sim 80 \%$ by 11 June (Fig. 6). Mortalities in the oysters cemented onto ropes were much lower at this time, reaching only $8 \%$ on 11 June. Oysters kept in Australian baskets outside of the farming area ('outside') in the Thau lagoon did not show any mortality between 27 May and 11 June. Therefore, both rearing structures and sites influenced mortality in the Thau lagoon $\left(\chi^{2}{ }_{11 \text { June }}\right.$ test, $\mathrm{p}<0.001$; inside/baskets $>$ inside/ropes $>$ outside/baskets).

The next group of oysters was transferred to the farming area of the Thau lagoon on 23 June 2010 and the mortality of these oysters (put in Australian baskets) was compared with that of the remaining oysters from the 27 May transfer cemented onto ropes and held in Australian baskets outside of the farming area. number analysed. Solid lines: pathogen detection thresholds. Dashed line in (A): threshold above which the herpesvirus is considered to be involved in mortality 
Table 2. Crassostrea gigas. Summary of 2-way repeated measures ANOVAs conducted on quantity of herpesvirus OsHV-1 and Vibrio splendidus DNA detected in oysters transferred to the Thau lagoon during Expts 2 and 3. Each of the 3 ANOVAs represents a seeding date, and each date of sampling is included as a repeated measure in all ANOVAs. 'Practice' is used as a generic term which includes both rearing structures and sites; nd: not detected. Bold: significance at $\mathrm{p}>0.05$

\begin{tabular}{|c|c|c|c|c|c|c|}
\hline \multirow{2}{*}{$\begin{array}{l}\text { Seeding } \\
\text { date }(\mathrm{d} / \mathrm{mo} / \mathrm{yr})\end{array}$} & \multirow{2}{*}{$\begin{array}{l}\text { Source } \\
\text { of variation }\end{array}$} & \multirow[t]{2}{*}{$\mathrm{df}$} & \multicolumn{2}{|c|}{ OsHV-1 } & \multicolumn{2}{|c|}{ V. splendidus } \\
\hline & & & $F$ & $\mathrm{p}$ & $F$ & $\mathrm{p}$ \\
\hline \multicolumn{7}{|c|}{ Expt 2: Seeding date and ploidy level } \\
\hline \multirow[t]{5}{*}{$12 / 03 / 2010$} & Ploidy & 1 & 1.5 & 0.264 & 0.2 & 0.652 \\
\hline & Between-subjects error & 6 & & & & \\
\hline & Date of sampling & 2 & 275.4 & $<0.001$ & 9.3 & 0.004 \\
\hline & Date $\times$ Ploidy & 2 & 3.4 & 0.067 & 0.1 & 0.950 \\
\hline & Within-subjects error & 12 & & & & \\
\hline \multirow[t]{5}{*}{$23 / 06 / 2010$} & Ploidy & 1 & 16.0 & 0.057 & nd & nd \\
\hline & Between-subjects error & 2 & & & & \\
\hline & Date of sampling & 4 & 7.5 & 0.008 & nd & nd \\
\hline & Date $\times$ Ploidy & 4 & 1.0 & 0.449 & nd & nd \\
\hline & Within-subjects error & 8 & & & & \\
\hline \multirow[t]{2}{*}{$17 / 09 / 2010$} & Ploidy & 1 & 1.6 & 0.278 & 2.9 & 0.167 \\
\hline & Error & 4 & & & & \\
\hline \multicolumn{7}{|c|}{ Expt 3: Rearing structures and sites } \\
\hline \multirow[t]{5}{*}{$27 / 05 / 2010$} & Practice & 2 & 6.4 & $<0.001$ & 4.9 & 0.055 \\
\hline & Between-subjects error & 6 & & & & \\
\hline & Date of sampling & 2 & 3.1 & 0.085 & 1.2 & 0.349 \\
\hline & Date $\times$ Practice & 4 & 1.2 & 0.366 & 2.1 & 0.144 \\
\hline & Within-subjects error & 12 & & & & \\
\hline \multirow[t]{5}{*}{ 23/06/2010 } & Practice & 2 & 78.9 & $<0.001$ & nd & nd \\
\hline & Between-subjects error & 6 & & & & \\
\hline & Date of sampling & 3 & 24.7 & $<0.001$ & nd & nd \\
\hline & Date $\times$ Practice & 6 & 8.2 & $<0.001$ & nd & nd \\
\hline & Within-subjects error & 18 & & & & \\
\hline \multirow[t]{2}{*}{$17 / 09 / 2010$} & Practice & 1 & 3.7 & 0.126 & 63.4 & 0.001 \\
\hline & Error & 16 & & & & \\
\hline
\end{tabular}

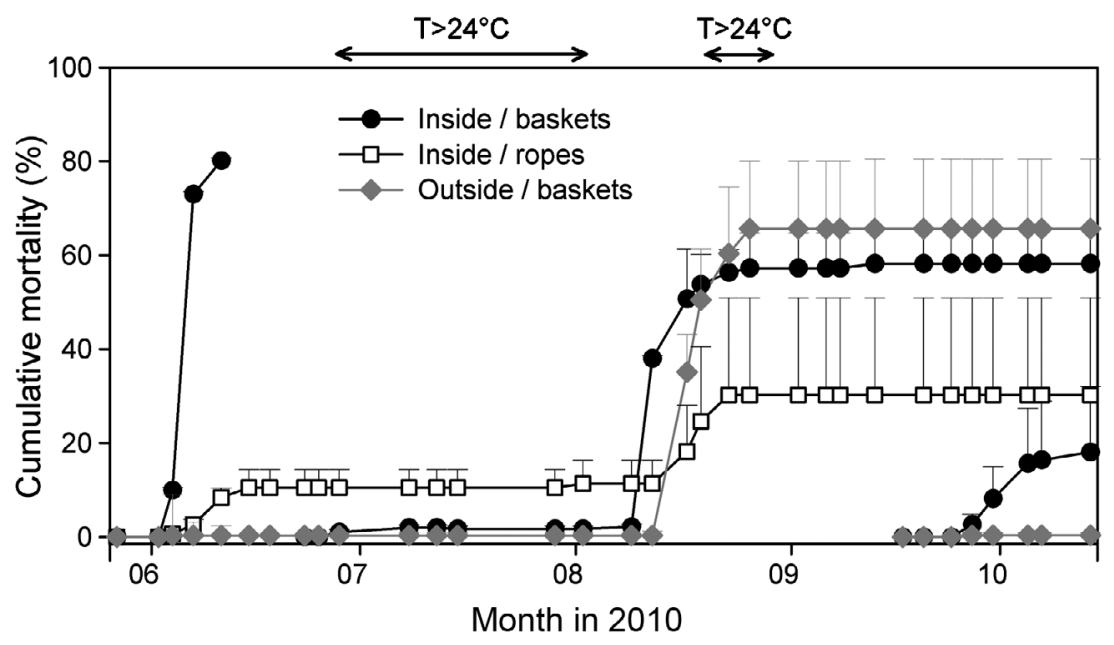

As observed in Expts 1 and 2, there was no oyster mortality until 9 August, i.e. as long as seawater temperature remained above $24^{\circ} \mathrm{C}$ (Fig. 6). Thereafter, seawater temperature decreased to below $24^{\circ} \mathrm{C}$ and mortalities severely hit the oysters in Australian baskets, both inside and outside of the bivalve farming area, reaching 57 and $66 \%$, respectively, on 26 August. At the same time, mortalities of oysters cemented to ropes increased by $20 \%$ (Fig. 6). Final cumulative mortalities were different among treatments $\left(\chi_{26}^{2}\right.$ August test, $\mathrm{p}<0.001$, inside $/$ baskets $=$ outside/baskets > inside/ropes).

It should be noted that the mortalities of the oysters maintained outside of the farming area occurred on 17 August 2010, 5 d after mortality began among oysters maintained inside the farming area (Fig. 6). Between 8 and 11 August, currents were relatively strong $\left(>30 \mathrm{~cm} \mathrm{~s}^{-1}\right)$ and oriented at $95^{\circ}$, so that water moved rapidly from the farming area towards the experimental site located outside of it (Fig. 7). This hydrodynamic configuration was observed twice in July when seawater temperature was $>24^{\circ} \mathrm{C}$ and no mortality occurred. These data suggest that mortalities spread as a function of hydrodynamics.

Fig. 6. Crassostrea gigas. Cumulative mortality (means + SD) of oysters, as a function of rearing structure and site (Expt 3). Before transfer on 27 May 2010, oysters were maintained in an area free of mortality in the open Mediterranean Sea. Oysters were either deployed inside the farming area in Australian baskets or cemented onto ropes, or outside the farming area in Australian baskets only ( $\mathrm{n}=3$ per rearing structure and site). Oysters were again transferred on 23 June and 17 September and put in Australian baskets to compensate for losses due to severe mortality 

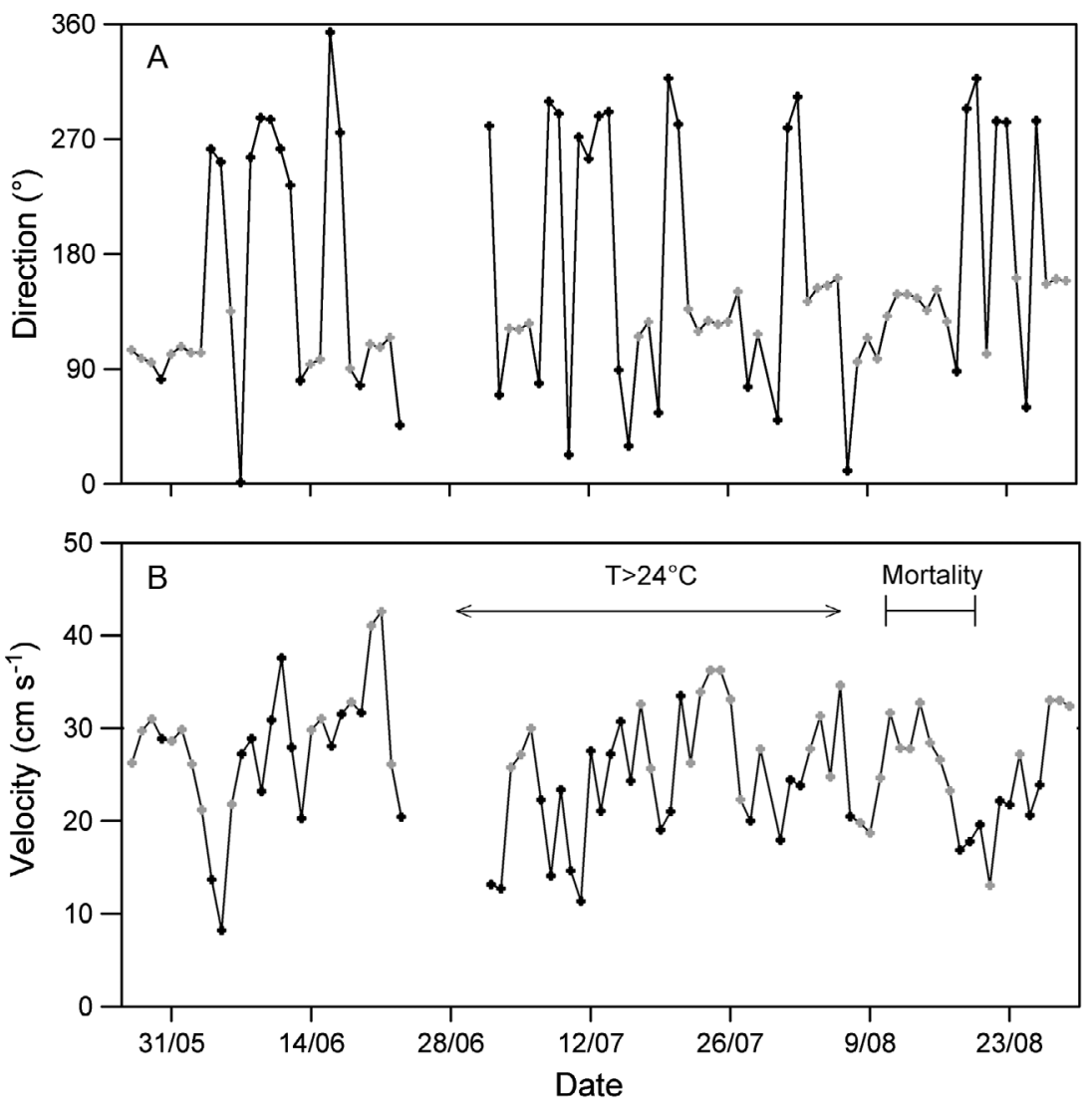

Fig. 7. Temporal variations in (A) direction and (B) velocity of currents at the experimental site located inside the farming area of the Thau lagoon. Grey dots indicate directions between $90^{\circ}$ and $170^{\circ}$ which correspond to seawater flowing from the farming area towards the experimental site located outside the farming zone

The final transferral was made on 17 September 2010, with oysters placed once again in Australian baskets both inside and outside of the farming area in Thau lagoon. Mortality attained $18 \%$ inside the farming area in mid-October, whereas there was no mortality outside of it at this time.

\section{Pathogens}

Herpesvirus. Detection frequency and quantity of OsHV-1 DNA in oysters transferred to the Thau lagoon on 27 May 2010 varied as a function of rearing structures and sites (Table 2, Fig. 8A). OsHV-1 detection frequency in oysters maintained free of mortality outside of the farming area was only $30 \%$ (8 out of 27) compared to $56 \%$ (30 out of 54 ) in oysters exposed to mortality inside the farming area (Fig. 8A, $\chi^{2}$ test: $\left.p=0.024\right)$. Also, the quantity of viral DNA in oysters maintained free of mortality outside of the farming area was only $1.3 \times 10^{2}$ DNA copy number $\mathrm{mg}^{-1}$ wet tissue compared with $1.5 \times$ $10^{6}$ DNA copy number $\mathrm{mg}^{-1}$ in oysters held inside the farming area (Fig. 8A; planned contrast between group means: inside vs. outside, $p=0.007$ ). Although mortality in oysters cemented onto ropes was much lower than that recorded in Australian baskets inside the farming area, detection frequencies and quantities of OsHV-1 DNA were generally similar between these 2 treatments (Fig. 8A, contrast analysis of inside/baskets vs. inside/ropes: detection frequency, $\chi^{2}$ test, $\mathrm{p}=0.396$, quantity, $F$-test, $\mathrm{p}=0.588$ ). It should be noted that, despite the fact that there was no overall Practice $\times$ Time effect (Table 2, where 'practice' includes both rearing structures and sites), detection frequency and quantity of OsHV-1 DNA in oysters cemented onto ropes decreased markedly between 7 June and 11 June, whereas it remained high in oysters held in Australian baskets inside the farming area (Fig. 8A).

Farming practices and time interacted in their effects on detection frequency and quantity of OsHV-1 DNA in oysters sampled between 15 July and 19 August 2010 in the Thau lagoon (Table 2, Fig. 8A). On 15 July, while no mortality occurred and seawater temperature was $>24^{\circ} \mathrm{C}$, detection frequency and quantity of OsHV-1 DNA in oysters were similarly low in all treatments (detection frequency, $\chi^{2}$ test, $p=0.751$; quantity, F-test, $\mathrm{p}=0.234$ ). On 12 August, detection frequency and quantity of OsHV-1 DNA increased markedly in oysters maintained in Australian baskets, which suffered heavy losses, whereas OsHV-1 was undetected in oysters cemented onto ropes, which showed no additional mortality (Fig. 8A; contrast analysis of baskets vs. ropes on 12 August: detection frequency, $\chi^{2}$ test, $\mathrm{p}<0.001$; quantity, F-test, $\mathrm{p}=0.004)$. At this point in time, quantities of OsHV-1 DNA in oysters were: inside/baskets > outside/baskets > inside/ropes. Then, between 17 and 23 August, the quantity of viral DNA decreased markedly in oysters held in Australian baskets, both inside and outside of the farming area, while mortalities stabilised. At this time, OsHV-1 DNA was detected at low levels in oysters cemented onto ropes, which showed additional mortalities (Fig. 8A). 

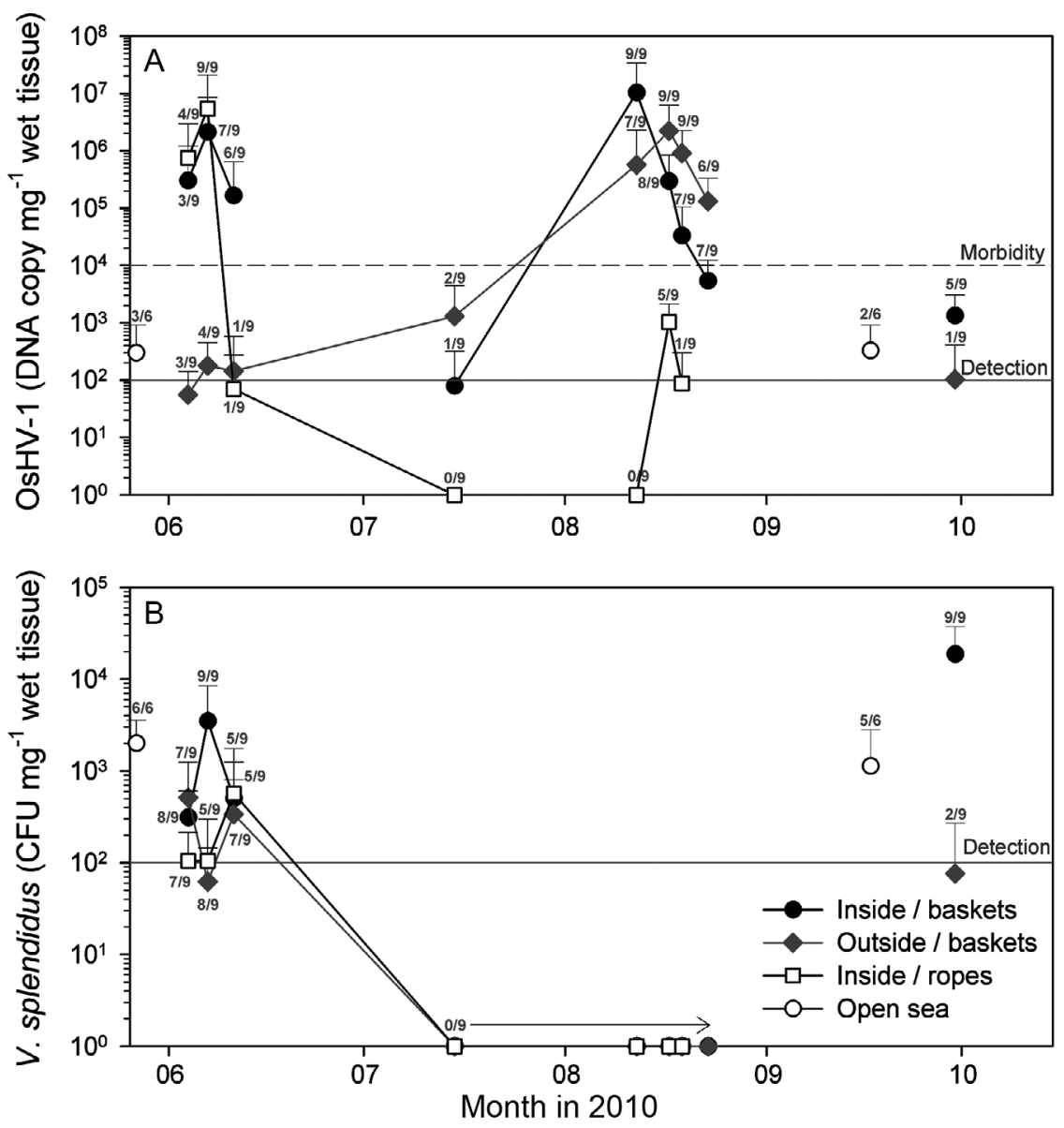

Fig. 8. Crassostrea gigas. Temporal variations in (A) herpesvirus OsHV-1 and (B) Vibrio splendidus abundance (means + SD) in oysters, as a function of rearing structure and distance to the mussel farming site in Thau lagoon (Expt 3). Before transfer on 27 May 2010, oysters were maintained in an area free of mortality in the open Mediterranean Sea. Values for oysters continuously reared in the open sea (open circles) are given for reference. Oysters were deployed inside the farming area in Australian baskets or cemented onto ropes, or outside the farming area in Australian baskets only ( $\mathrm{n}=3$ nets for each rearing structure and site). Oysters were again transferred on 23 June and 17 September in Australian baskets to compensate for the losses due to severe mortality. DNA detection of herpesvirus and $V$. splendidus were conducted on 3 individual oysters per Australian basket or rope ( $\mathrm{n}=9$ individuals per treatment). Fractions indicate the number of infected individuals or nets when several oysters were pooled, compared to the total number analysed. Solid lines: pathogen detection thresholds. Dashed line in (A): threshold above which the herpesvirus is considered to be involved in mortality

Finally, detection frequency and quantity of OsHV1 DNA in oysters transferred to the Thau lagoon on 17 September remained low irrespective of site (Fig. 8A; detection frequency $\chi^{2}$ test, $\mathrm{p}=0.066$; quantity, F-test, see Table 2).

Vibrio splendidus. There was no significant effect of farming practice and time on detection frequency of Vibrio splendidus in oysters transferred to the Thau lagoon on 27 May 2010 (Fig. 8B; detection frequency, $\chi^{2}$ tests, $\mathrm{p}>0.089$; quantity, F-test, Table 2).
However, the p-value for the effect of farming practice on quantity of $V$. splendidus DNA in oysters was 0.055 , which is very close to the generally accepted threshold value of 0.05 for the rejection of the null hypothesis. Furthermore, multiple comparison tests revealed that the mean quantity of $V$. splendidus DNA in oysters cemented onto ropes $\left(2.6 \times 10^{2}\right.$ DNA copy number $\mathrm{mg}^{-1}$ wet tissue) was one order of magnitude lower than that of oysters held in Australian baskets inside the farming area $\left(1.4 \times 10^{3}\right.$ DNA copy number $\mathrm{mg}^{-1}$ wet tissue, $\mathrm{p}=0.020$ ) and similar to that of oysters held outside of the farming area $(3.0 \times$ $10^{2}$ DNA copy number $\mathrm{mg}^{-1}$ wet tissue, $\mathrm{p}=0.187$; Fig. 8B).

Vibrio splendidus was not detected in oysters sampled between 15 July to 23 August 2010, as observed in Expts 1 and 2. Detection frequency and quantity of $V$. splendidus DNA in oysters transferred to the Thau lagoon on 17 September and sampled on 30 September were higher in oysters kept inside the farming area, where mortalities were occurring, than in oysters kept outside of the farming area, where no mortality occurred at this time of the year (Fig. 8B; detection frequency $\chi^{2}$ test, $\mathrm{p}=$ 0.002 ; quantity, F-test, see Table 2 ).

\section{Energetic parameters}

Overall, the transfer of oysters to the Thau lagoon on 27 May 2010 led to an enhancement of their energetic reserves by 4 June 2010: 1.3 to 1.6 times for total carbohydrate and 1.8 to 3.8 times for TAG, depending on rearing structures and sites. On 4 June, energetic reserves in oysters transferred to the Thau lagoon were ranked as follows: inside/ropes $\geq$ inside/baskets $\geq$ outside/baskets (Table 3). CS activity varied inversely with energetic reserves: inside/ropes $\leq$ inside/baskets $\leq$ outside/baskets (Table 3). Activities of HK, PK and PEPCK were not influenced by farming practices 
Table 3. Crassostrea gigas. Effects of rearing structure and site (Expt 3) on energetic resources. Concentrations of carbohydrate $(\mathrm{CH})$ and triacylglycerols (TAG), and activities of citrate synthase (CS), hexokinase (HK), pyruvate-kinase (PK) and phospho-enolpyruvate-carboxykinase (PEPCK), and PK:PEPCK ratio in oysters when mortality began on 4 June 2010 (means \pm SD). Oysters were maintained in an area free of mortality in the open Mediterranean Sea before being transferred to the Thau lagoon on 27 May 2010. Oysters were either deployed inside the farming area in Australian baskets or cemented onto ropes, or outside the farming area in Australian baskets only ( $\mathrm{n}=3$ for each rearing structure and site). Reference value recorded on 27 May 2010 before seeding. Significant $(p<0.05) p$ values are indicated in bold. Different letters indicate significant differences between means

\begin{tabular}{|c|c|c|c|c|c|}
\hline Parameter & Reference & $\begin{array}{l}\text { Inside/ } \\
\text { ropes }\end{array}$ & $\begin{array}{c}\text { - Deployment - } \\
\text { Inside/ } \\
\text { baskets }\end{array}$ & $\begin{array}{l}\text { Outside/ } \\
\text { baskets }\end{array}$ & $\mathrm{p}$ \\
\hline \multicolumn{6}{|c|}{ Energetic reserves (mg g ${ }^{-1}$ dry mass) } \\
\hline $\mathrm{CH}$ & 129.3 & $210.0^{\mathrm{a}} \pm 28.8$ & $192.5^{\mathrm{ab}} \pm 29.8$ & $167.3^{\mathrm{a}} \pm 35.8$ & 0.024 \\
\hline TAG & 8.8 & $33.5^{\mathrm{a}} \pm 7.7$ & $22.3^{b} \pm 8.5$ & $15.7^{\mathrm{b}} \pm 6.0$ & $<0.001$ \\
\hline \multicolumn{6}{|c|}{ Enzyme activities (mU mg ${ }^{-1}$ protein) } \\
\hline $\mathrm{CS}$ & 53.9 & $55.3^{\mathrm{b}} \pm 6.7$ & $60.5^{\mathrm{ab}} \pm 3.3$ & $61.3^{\mathrm{a}} \pm 3.0$ & 0.023 \\
\hline HK & 3.9 & $7.0 \pm 1.9$ & $6.9 \pm 1.5$ & $7.3 \pm 2.1$ & 0.881 \\
\hline PK & 1.4 & $2.4 \pm 0.7$ & $2.7 \pm 1.2$ & $2.7 \pm 0.8$ & 0.773 \\
\hline PEPCK & 2.8 & $6.0 \pm 2.4$ & $7.3 \pm 4.5$ & $3.9 \pm 1.6$ & 0.093 \\
\hline \multicolumn{6}{|c|}{ Ratio of enzyme activities } \\
\hline PK:PEPCK & 0.67 & $0.44^{\mathrm{b}} \pm 0.18$ & $0.43^{\mathrm{b}} \pm 0.21$ & $0.72^{\mathrm{a}} \pm 0.21$ & 0.008 \\
\hline
\end{tabular}

Table 4. Crassostrea gigas. Effects of pathogen infection (Expt 3) on energetic resources. Concentration of carbohydrate and triacylglycerols (TAG), and activities of citrate synthase (CS), hexokinase (HK), pyruvate-kinase (PK), phosphoenolpyruvate-carboxykinase (PEPCK) and PK:PEPCK ratio in oysters on 4 June 2010 (means \pm SD), as a function of their pathological status. These oysters were first maintained in an area free of mortality in the open Mediterranean Sea and then transferred to the Thau Lagoon on 27 May 2010. They were deployed inside the farming area in Australian baskets or cemented onto ropes, or outside the farming area in Australian baskets only. Significant $(p<0.05) p$-values are indicated in bold. Different letters indicate significant differences between means

\begin{tabular}{|c|c|c|c|c|c|}
\hline Variable & $\begin{array}{c}\text { No } \\
\text { detection }\end{array}$ & OsHV-1 & $\begin{array}{l}V . \text { splen- } \\
\text { didus }\end{array}$ & $\begin{array}{c}\text { OsHV-1 + } \\
\text { V. splendidus }\end{array}$ & $\mathrm{p}$ \\
\hline \multicolumn{6}{|c|}{ Energetic reserves (mg g ${ }^{-1}$ dry mass) } \\
\hline Carbohydrate & $202^{\mathrm{a}} \pm 36$ & $212^{\mathrm{a}} \pm 49$ & $167^{\mathrm{b}} \pm 27$ & $200^{\mathrm{a}} \pm 12$ & 0.044 \\
\hline TAG & $25 \pm 7$ & $26 \pm 5$ & $20 \pm 14$ & $27 \pm 8$ & 0.492 \\
\hline \multicolumn{6}{|c|}{ Enzyme activity (mU mg ${ }^{-1}$ protein) } \\
\hline $\mathrm{CS}$ & $59.4 \pm 4.9$ & $55.3 \pm 4.3$ & $60.3 \pm 5.7$ & $59.0 \pm 5.5$ & 0.461 \\
\hline HK & $8.6^{\mathrm{a}} \pm 2.4$ & $6.9^{\mathrm{b}} \pm 0.8$ & $6.8^{\mathrm{b}} \pm 1.3$ & $6.0^{\mathrm{b}} \pm 1.3$ & 0.047 \\
\hline PK & $2.6 \pm 0.8$ & $2.3 \pm 0.9$ & $2.3 \pm 0.8$ & $3.2 \pm 1.2$ & 0.312 \\
\hline PEPCK & $5.2 \pm 1.8$ & $6.4 \pm 3.4$ & $6.4 \pm 4.8$ & $4.9 \pm 1.1$ & 0.794 \\
\hline \multicolumn{6}{|c|}{ Ratio of enzyme activities } \\
\hline PK:PEPCK & $0.5 \pm 0.2$ & $0.4 \pm 0.2$ & $0.5 \pm 0.3$ & $0.6 \pm 0.2$ & 0.503 \\
\hline
\end{tabular}

Analysis of the effect of the pathological status of the oysters suggested that energetic parameters had no effect on detection of OsHV-1 DNA (Table 4). However, the level of carbohydrate in oysters infected by Vibrio splendidus alone was lower than that of oysters free of both $V$. splendidus and OsHV-1, and of oysters infected by OsHV-1 alone. Activity of $\mathrm{HK}$, a key enzyme of the glycolysis pathway was lower in oysters infected by $V$. splendidus and herpesvirus OsHV-1 than in oysters free of these 2 pathogens (Table 4).

\section{Previous exposure to mortality risks (Expt 4)}

One-yr-old 2n and 3n oysters maintained in a mortality-free site in the open Mediterranean Sea in 2010 showed 70 and $25 \%$ mortality, respectively, during spring 2011, when seawater temperature attained $17^{\circ} \mathrm{C}$ (Fig. 9). In contrast, oysters from the same origin and of the same age previously exposed to a mortality event during the summer 2010 exhibited only $\sim 7 \%$ mortality irrespective of ploidy level. Another batch of oysters produced in 2010 showed mass mortality (>90\%) during this period.

\section{DISCUSSION}

\section{Seasonality in oyster mortalities and pathogens}

The present study clearly shows that oyster mortalities occurred when seawater temperature was

(Table 3). However, the transfer of oysters to the Thau lagoon enhanced the activities of $\mathrm{HK}, \mathrm{PK}$ and to a lesser extent, PEPCK. PK/PEPCK of oysters maintained in mortality-free areas outside of the farming area was 1.7 times higher than that of oysters held inside the farming area, where mortality occurred (Table 3). between 17 and $24^{\circ} \mathrm{C}$ during the spring, summer and early autumn in the Thau lagoon (Figs. 2, 5 \& 8). Mortalities started during the spring when seawater temperature reached $17^{\circ} \mathrm{C}$. These mortalities always coincided with elevated detection frequency and quantity of OsHV-1 DNA ( $>10^{4}$ copies DNA mg $^{-1}$ wet tissue) and Vibrio splendidus $\left(>10^{3}\right.$ copies DNA mg ${ }^{-1}$ 


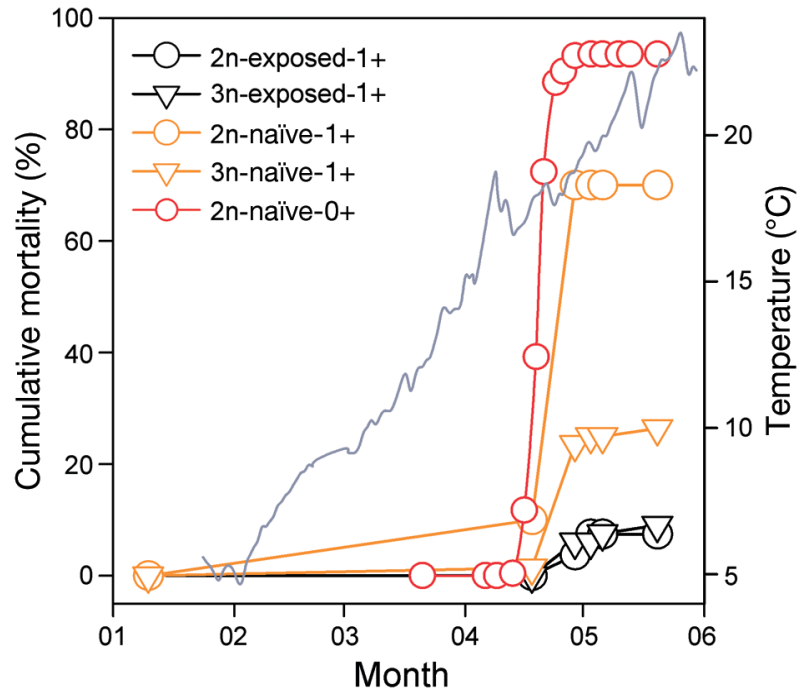

Fig. 9. Crassostrea gigas. Cumulative mortality of naïve and non-naïve oysters in the Thau lagoon in 2011 (Expt 4). Diploid (2n) and triploid (3n) oysters were maintained in an area free of mortality in the open Mediterranean Sea before being transferred to the Thau lagoon. One subsample of 1yr-old $2 n$ and $3 n$ oysters was transferred on 23 June 2010 and was exposed to the mortality during the summer (nonnaïve, i.e. exposed group). Another subsample of oysters (naïve group) was transferred later, on 10 January 2011 during the winterly cessation of mortality. Cumulative mortality of $2 \mathrm{n}$ oysters produced in summer 2010, maintained free of mortality until transfer to the lagoon on 12 March 2011 is also shown. Seawater temperatures are indicated in grey. Age classes $1+(>1 \mathrm{yr}$ olds $)$ and $0+(>0 \mathrm{yr}$ olds $)$ are also indicated

wet tissue) in oysters, thus suggesting that these 2 pathogens are involved in triggering the mass mortality phenomenon in the Thau lagoon. Laboratory experiments show that either herpesvirus OsHV-1 or $V$. splendidus alone can cause death in oysters (e.g. De Decker et al. 2011, Schikorski et al. 2011a). Although the effect of co-infection by herpesvirus and $V$. splendidus has not yet been investigated, it is likely that they exhibit synergistic virulence effects. Such a synergistic virulence effect was observed between 2 pathogenic bacterial strains of $V$. splendidus and $V$. aestuarianus when they were injected simultaneously into oysters (Saulnier et al. 2010), and the phenomenon has also been reported in oysters infected with 2 strains related to $V$. splendidus (Gay et al. 2004).

During the summer, when seawater temperature was close to $24^{\circ} \mathrm{C}$, mortality patterns coincided with the elevated detection frequency and quantity of OsHV-1 DNA, whereas Vibrio splendidus DNA was not detected in oysters (Figs. 3, 6 \& 9). Therefore, it seems that $V$. splendidus is not necessarily associated with the oyster mortalities. This result agrees with previous studies which show that $V$. splendidus is frequently, but not systematically, associated with oyster summer mortalities (Garnier et al. 2007). Additionally, the fact that $V$. splendidus DNA is not detected in oysters when seawater temperature is $\sim 24^{\circ} \mathrm{C}$ during the summer likely reflects seasonal influences of environmental parameters such as temperature, salinity and plankton on the Vibrio communities of the Thau lagoon (see e.g. Thompson et al. 2004, Oberbeckmann et al. 2011).

During the summer, when seawater temperature was $>24^{\circ} \mathrm{C}$, no mortality was observed, and OsHV-1 and Vibrio splendidus DNA were not detected in oysters held in the Thau lagoon (Figs. 2, 5 \& 8). Similar observations were reported in oysters maintained in ponds along the Atlantic coast of France during summer (Bouquet et al. 2011). In contrast, larvae of Crassostrea gigas experimentally challenged with herpesvirus OsHV-1 exhibited mass mortality at 25 to $26^{\circ} \mathrm{C}$ (Le Deuff et al. 1996). Similarly, elevated temperature influences the detection of herpesvirus by promoting an earlier production of viral particles, resulting in a rapid spread of the disease and massive mortalities in juvenile oysters (Sauvage et al. 2009). Sauvage et al. (2009) reported that mortality in infected oysters occurred when seawater temperature was $23.8^{\circ} \mathrm{C}$. Therefore, it is possible that the upper temperature threshold of virulence of the emergent OsHV-1 $\mu$ Var genotype is lower than that of the reference strain. Alternatively, arrested oyster mortality and absence of detection of herpesvirus OsHV-1 may also reflect influences of environmental parameters on the dynamics of herpesvirus OsHV-1 $\mu$ Var.

During autumn, mortalities generally coincided with detection of OsHV-1 and Vibrio splendidus DNA when seawater temperature was $>17^{\circ} \mathrm{C}$. However, the increase of these 2 pathogens during autumn oyster mortalities was not systematic in the same way as during spring mortalities. For example, autumn mortality of oysters in Expt 1 was only 18\% (Fig. 2) and coincided with a slight increase in herpesvirus OsHV1 and V. splendidus (Fig. 3). In Expt 2, autumn mortalities were much higher than in Expt 1, reaching 54 and $83 \%$ in $3 n$ and $2 n$ oysters, respectively (Fig. 4 ), and coinciding with a marked increase in herpesvirus and an increase in $V$. splendidus exclusively in $2 \mathrm{n}$ oysters (Fig. 5). Therefore, mortality of oysters and presence of their pathogens during autumn varied according to oyster batch characteristics, such as age and ploidy level. However, our results clearly show that autumn mortalities are characterised by the detection of $V$. splendidus DNA in oysters.

Finally, once seawater temperature dropped below $17^{\circ} \mathrm{C}$ during autumn, no additional mortality was re- 
corded until the following spring. Pathogen analyses conducted on oysters sampled on 12 March 2010 in the Thau lagoon showed that the quantity of OsHV-1 DNA was $<10^{2}$ copies DNA mg $^{-1}$ wet tissue (Fig. 5). It is therefore likely that herpesvirus is either absent or latent in oysters when seawater temperature is $<17^{\circ} \mathrm{C}$. Similarly, a 2-yr monitoring study conducted in Normandy showed that detection frequency and quantity of OsHV-1 DNA in oysters are low in the period between October and April, when no mortality occurs (Oden et al. 2011). Also, it is generally accepted that overwintering temperatures are not favourable to the growth of pathogenic bacteria of the Vibrio splendidus group (Garnier et al. 2007). Therefore, the absence of oyster mortality between October and April in the Thau lagoon likely reflects the absence of herpesvirus OsHV-1 and V. splendidus.

\section{Oyster mortalities and pathogens vary among farming sites}

Oyster mortalities have occurred every year since 2008 in the Thau lagoon and coincided with high detection frequency and quantity of OsHV-1 DNA (see previous section and Pernet et al. 2010). In contrast, oysters maintained at our experimental site in the open Mediterranean Sea showed no mortality between March 2008 and May 2011 (data not shown), and herpesvirus OsHV-1 was generally undetected or only detected at low levels (Fig. 3). This experimental site, which is at an off-shore mussel farm $\sim 7 \mathrm{~km}$ from the channels connecting the Thau lagoon to the sea, is $22 \mathrm{~m}$ deep and is not connected to the Thau lagoon in terms of hydrodynamics (Fig. 1). Although seawater temperature at the open sea site was markedly lower than that in Thau lagoon, it was often $>17^{\circ} \mathrm{C}$ during the summer (Fig. 2). Despite the fact that OsHV-1 DNA was occasionally detected at a low level in oysters deployed in the open sea and that seawater temperature between 17 and $24^{\circ} \mathrm{C}$ coincided with disease outbreak in the Thau lagoon, there was no mortality in the open sea. This likely reflects the effect of other environmental parameters, but this needs further investigation.

Oysters deployed inside the farming area of the Thau lagoon on 27 May 2010 showed $~ 80 \%$ mortality after only $10 \mathrm{~d}$ (Fig. 6), which coincided with an elevated detection frequency and quantity of OsHV-1 DNA (Fig. 8A). Oysters deployed outside the farming area of the Thau lagoon at the same time showed no mortality until 17 August 2010, and herpesvirus OsHV-1 was undetected or below morbidity thresh- old. Differences in oyster mortality between these 2 sites within the Thau lagoon coincided with differences in detection frequency and quantity of OsHV-1 DNA.

After 17 August 2010, mortalities severely hit the oysters maintained outside of the farming area. This situation likely reflects an effect of hydrodynamics. Between 8 and 11 August, currents were relatively strong and waters moved from the farming area, where mortality occurred and herpesvirus was detected, towards the experimental site outside the farming area where oysters had been free of mortality. The sites therefore became connected via currents. Five days later, mortalities occurred in the oysters maintained outside the farming area, concomitantly with the detection of the herpesvirus (Figs. 6 \& 8A).

Considered together, these results suggest that oyster mortalities coincide with infection by herpesvirus OsHV-1 and that mortality spreads between infected and healthy oysters as a result of hydrodynamic connectivity. Large-scale studies of factors associated with the risk of contracting pancreas disease in farmed salmonids have found that the most important factor is the infectious status of nearby farms, suggesting horizontal spread of salmonid alphavirus between neighbouring farms (Kristoffersen et al. 2009). In a hydrodynamic modelling study, Viljugrein et al. (2009) concluded that pancreas disease is likely to be spread by passive drift of salmonid alphavirus in the water current. Another study showed that the hydrodynamic regime partly explained the spatio-temporal distribution of infectious salmon anaemia outbreaks - a disease caused by the infectious salmon-anemia virus (Gustafson et al. 2007) among Atlantic salmon farms. In our study, the observed 5-d delay between outbreaks occurring inside and outside the farming area agree well with the incubation times noted for laboratory cohabitation with oysters infected with herpesvirus OsHV-1 (Schikorski et al. 2011a).

From a practical standpoint, these results show that it is possible to rear oysters free of mortality in the open Mediterranean Sea. However, these naïve oysters remain susceptible to the disease and still require protection during their first $2 \mathrm{yr}$.

\section{Oyster mortalities and pathogens vary with farming practices}

Our study shows that naïve oysters maintained free of mortality in the open sea and then transferred to 
the Thau lagoon and put in Australian baskets exhibited mass mortalities during the first $2 \mathrm{yr}$, suggesting that there is no increase in resistance with age. However, when oysters maintained free of mortality in the open sea were transferred to the Thau lagoon and then cemented onto ropes, the oysters showed only $\sim 30 \%$ mortality during the entire production cycle, compared with $80 \%$ for those in Australian baskets. It is therefore possible that age and rearing structure interact in their effects on oyster mortality. Also, similar transfer experiments conducted in Brittany revealed that 1-yr-old oysters maintained under mortality-free conditions showed very low mortality the year after, when seeded into an infectious environment (B. Petton pers. comm.). It is therefore possible that the Age $\times$ Site interaction affects mortality, as previously reported (Dégremont et al. 2010b). It should, however, be noted that the ontogeny of resistance to viral and bacterial disease in oysters is virtually unknown. Only a few studies have investigated the ontogeny of the immune system of oysters; these used genomic approaches (Montagnani et al. 2005, Tirapé et al. 2007).

Although naïve oysters remained susceptible to infections inducing mortality during their first $2 \mathrm{yr}$, oysters that survived a mass mortality event were then resistant, as previously reported by Dégremont et al. (2010b). Oysters that had survived a mortality event were thus naturally selected for resistance to the disease. A positive response to artificial selection was observed following organised divergent selection for increased and decreased survival according to family responses during a summer mortality outbreak in Crassostrea gigas (Dégremont et al. 2010a). This result was confirmed in the context of the new massive mortalities occurring in France in 2009 (Dégremont 2011). Together, these results indicate that selective breeding programmes could improve oyster survival. From a practical standpoint, it seems preferable to expose oysters to mortality at an early age in order to select resistant individuals at low cost rather than maintaining naïve oysters that remain susceptible to disease during their first $2 \mathrm{yr}$ in the Thau lagoon.

Mortalities of $2 \mathrm{n}$ and $3 \mathrm{n}$ oysters were similar during spring, as previously reported by Pernet et al. (2010). However, during the summer and autumn, mortalities of $2 \mathrm{n}$ oysters were double those occurring in $3 n$ oysters. This could reflect an interaction effect between seasons and ploidy levels on reproductive effort (Normand et al. 2008) and immunological parameters (Gagnaire et al. 2006). Differences in mortality between $2 \mathrm{n}$ and $3 \mathrm{n}$ oysters may not only reflect the effect of ploidy level, but also that of other factors, such as their genetic makeup. It is possible that the $3 n$ oysters used in this study were genetically 'resistant', whereas $2 \mathrm{n}$ oysters were more 'susceptible', in addition to any difference conferred by their ploidy level. Although both $2 \mathrm{n}$ and $3 \mathrm{n}$ oysters exhibited a high quantity of OsHV-1 DNA, 3n individuals contained lower level proliferations and eliminated the viral DNA from their tissue more rapidly than $2 n$ oysters. Similar differences in OsHV-1 dynamics between $3 \mathrm{n}$ and $2 \mathrm{n}$ oysters were previously reported when comparing oysters selected for resistance and susceptibility to summer mortality (Dégremont 2011).

Mortalities of oysters in the Thau lagoon were markedly influenced by the rearing structures used. During spring 2010, oysters transferred to the Thau lagoon exhibited $\sim 80 \%$ mortality in Australian baskets compared with only $8 \%$ in oysters cemented onto ropes. However, detection frequency and quantity of OsHV-1 DNA were similar between rearing structures. Therefore, it seems that high detection frequency and quantity of OsHV-1 DNA do not necessarily coincide with high mortality rate in oysters, as has previously been reported in resistant oysters (Dégremont 2011). It should also be noted that the oysters cemented onto ropes eliminated the viral DNA from their tissue more rapidly than those held in Australian baskets. Similar differences in virus dynamics were previously reported when comparing $3 \mathrm{n}$ and $2 \mathrm{n}$ oysters (present study) and resistant and susceptible oysters (Dégremont 2011). It seems that the capacity to rapidly eliminate the viral DNA is linked with virus resistance and survival in oysters.

Differences in oyster mortalities between rearing structures also coincided with higher quantities of Vibrio splendidus DNA and lower levels of energetic reserves (particularly TAG) in oysters held in Australian baskets compared with oysters cemented onto ropes. The present study shows for the first time that rearing conditions simultaneously influenced mortality, the elimination of OsHV-1 DNA, the proliferation of $V$. splendidus and oyster energetic status. However, it is not possible to determine causal relationships among these parameters and their relative influence on mortality based on this experiment.

The limited proliferation of Vibrio splendidus and greater elimination of viral DNA among oysters cemented onto ropes likely reflects the lower host density, absence of contact and movement among oysters, and better circulation of water around each individual, compared with oysters held in baskets. Firstly, in our experiment, density of oysters in Australian baskets was at least 6 times higher than that of 
oysters cemented onto ropes. Dynamics of infectious diseases are related to the density of host populations (e.g. Krkošek 2010). High densities of host populations generally lead to increased contact rates between susceptible host individuals and hosts containing pathogens, resulting in increased transmission and persistence of disease, whereas low host densities decrease the rate of encounter between susceptible host individuals and hosts with pathogens, resulting in slower disease spread and, eventually, disease eradication. Secondly, physical contact and movement among oysters under wave action probably enhanced contact rates between susceptible hosts within the Australian baskets. In contrast, there was no physical contact among oysters when they were cemented onto ropes. Thirdly, the circulation of seawater around individual oysters regularly spaced along a rope is probably much better than that occurring within crowded Australian baskets. It is generally accepted that the extent to which flows are modified depends on attributes of the cultivation structures such as height and density (e.g. Forrest et al. 2009). Small scale hydrodynamics are likely to be an important factor for flushing pathogens from rearing units.

Oysters cemented onto ropes showed higher levels of energetic reserves than oysters held in baskets. This may be because stocking density in Australian baskets was higher than on ropes. For instance, many studies have shown that growth is inversely proportional to stocking density due to intraspecific competition for resources (Holliday et al. 1991, Côté et al. 1994, Taylor et al. 1997, Maguire \& Burnell 2001, Mazón-Suástegui et al. 2008) and food depletion within the boundary layer (Fréchette et al. 1989). Scallops cultured at low densities were thus seen to have a higher carbohydrate content during the summer than those cultured at high densities (Maguire \& Burnell 2001). In our study, rearing structure had a particularly clear effect on TAG, while its effect on carbohydrate was not significant. Alternatively, the lower levels of energetic reserves in oysters held in Australian baskets could also be explained by the fact that they are exposed to shocks caused by wave action, thus causing frequent valve closures and consequently, a decrease in feeding time (Côté et al. 1994).

During summer 2010, mortality of oysters in Australian baskets was again much higher than that of oysters cemented onto ropes, as observed the previous spring. The situation in 2010 differed in that detection frequency and quantity of OsHV-1 DNA were markedly higher in oysters held in Australian baskets than in oysters cemented onto ropes. Addi- tionally, detection frequency and quantity of OsHV-1 DNA in oysters cemented onto ropes were much lower during the summer than spring. This may be because oysters that have survived a previous exposure to the herpesvirus are better able to limit its proliferation. Vibrio splendidus was not detected in either type of rearing structure in this part of the study, confirming that these bacteria are not systematically associated with oyster mortalities.

\section{Relationships between oyster mortalities, patho- gens and energetic parameters}

Considered separately, oysters cemented to ropes showed lower mortality, limited proliferation of herpesvirus OsHV-1 and lower levels of Vibrio splendidus (Figs. 6 \& 8), and significantly $(\mathrm{p}<0.001)$ higher levels of TAG than oysters held in Australian baskets (Table 3). A similar result was found in a previous study where the TAG concentrations in sea scallop larvae treated with an antibiotic were higher compared with scallops exposed to Vibrio spp., suggesting that antibiotic treatment enhanced the condition of sea scallops by reducing the amount of energy allocated to defence (Pernet et al. 2006). Viral and bacterial infections also reduce the lipid content in several crustacean species (Stuck \& Overstreet 1994, Stuck et al. 1996, Floreto et al. 2000). It is therefore possible that a high level of TAG in oysters could enhance their resistance to pathogen-related mortality events. However, in our present study, the level of TAG was similar in infected and healthy oysters (Table 4). Consequently, the higher level of TAG in oysters cemented onto ropes reflects their better nutritional condition, which enhances their resistance to mortality compared with oysters held in baskets.

Carbohydrate concentration and activities of key enzymes related to glycolysis and gluconeogenesis in oysters cemented onto ropes were similar to those held in baskets (Table 3). Nevertheless, oysters infected by Vibrio splendidus had a lower level of carbohydrate than oysters free of both pathogens and oysters infected by herpesvirus alone (Table 4). Similarly, young clams Ruditapes philippinarum infected by the pathogen $V$. tapetis showed a significant decrease in glycogen compared with healthy clams (Plana et al. 1996). However, it is still unclear why the level of carbohydrate in oysters co-infected by $V$. splendidus and herpesvirus was similar to that of oysters free of these 2 pathogens (Table 4 ).

In our study, activity of HK, a key enzyme of the glycolysis pathway, was lower in oysters infected by 
Vibrio splendidus and herpesvirus OsHV-1, or both, compared with that of oysters free both of these pathogens (Table 4). Activity of HK in labial palps of oysters varies with feeding ration (Bacca 2007, p. 123). Therefore, the reduction in HK activity observed in infected oysters may reflect a decrease in feeding activity, which is symptomatic of pathogen infection in bivalves (Flye-Sainte-Marie et al. 2007, Genard et al. 2011).

Oysters cemented onto ropes, which showed lower mortality and pathogen infection and higher levels of TAG, also had lower CS activity than oysters held in Australian baskets (particularly for those maintained outside of the farming area, Table 3). Several studies on marine invertebrates have shown that CS activity and respiration rate are positively correlated (Moran \& Manahan 2004, Meyer et al. 2007). The lower CS activities in oysters cemented onto ropes could indicate a lower respiration rate compared with oysters held in Australian baskets. However, CS activity was similar regardless of the pathological status of oysters (Table 4). This result contrasts with a previous report of decreased CS and cytochrome oxidase activities during a mortality event in Crassostrea virginica larvae (Genard et al. 2011). Similarly, in juvenile Manila clams, respiration rate decreased with the development of brown ring disease symptoms (Flye-SainteMarie et al. 2007). The relationship between CS activities, aerobic metabolism and pathogen proliferation in bivalves therefore needs further investigation.

\section{CONCLUSION}

The present study provides the first comprehensive view of the mass mortality phenomenon in Pacific oysters Crassostrea gigas in the Thau lagoon, French Mediterranean Sea, in relation to 2 pathogens, herpesvirus OsHV-1 and bacteria belonging to the group Vibrio splendidus. Mortalities of oysters always coincided with single or co-infections, involving primarily herpesvirus OsHV-1 and secondarily the bacteria $V$. splendidus, when seawater temperature ranged from 17 to $24^{\circ} \mathrm{C}$. In the Thau lagoon, mortality started in early May and continued until autumn, with an interruption period in July and August when seawater temperature is $>24^{\circ} \mathrm{C}$.

From a practical standpoint, the present study shows that oyster mortalities and pathogens varied among farming sites in a way that was consistent with the hydrodynamic regime and connectivity among infected areas. Consequently, it is still possible to rear oysters away from mortality risks, notably at our experimental site located in the open Mediterranean Sea. In addition, levels of oyster mortalities and pathogens varied with farming practices. Naïve oysters remained susceptible to pathogen-related mortality during their first $2 \mathrm{yr}$, whereas oysters that had survived a mass mortality event in the past were subsequently resistant. This result underlines that selective breeding programmes could improve oyster survival and suggests that growers may benefit from exposing oysters to mortality risks as early in the rearing process as possible to select resistant individuals at low cost. Finally, oyster mortalities were much lower in oysters cemented onto ropes than in oysters held in Australian baskets, reflecting differences in proliferation of herpesvirus OsHV-1, quantities of Vibrio splendidus and energetic reserves of oysters.

Acknowledgements. The authors thank Hélène Boulet, Pierre Besrest, Solenn Soriano, Eve-Julie Arsenault-Pernet, Marine Miguet, and Anaïs Crottier for their careful lab work. The authors also thank the staff involved in the shellfish networks (Observatoire Conchylicole) and the staff involved in oyster production (Ifremer hatchery and nursery teams). Finally, the authors express their gratitude to Helen McCombie for revising the English version of this manuscript. This work was supported by grants from Région Languedoc-Roussillon, Conseil Général de l'Hérault, Fond Européen pour la Pêche and Comité Régionale de Conchylicole de Méditerranée to the Ifremer ADECOM project.

\section{LITERATURE CITED}

Bacca H (2007) Étude des voies métaboliques des sucres chez l'huître creuse Crassostrea gigas. Implication dans les mortalités estivales. PhD thesis, Université de Rennes I, Rennes

Barnabé G, Doumenge F (2001) Mariculture of Mediterranean species. In: John HS (ed) Encyclopedia of ocean sciences. Academic Press, Oxford, p 1567-1572

Bédier E (2010) Observatoire national Conchylicole. Rapport 2009, Ifremer, La Trinité

Berthelin C, Kellner K, Mathieu M (2000) Storage metabolism in the Pacific oyster (Crassostrea gigas) in relation to summer mortalities and reproductive cycle (West coast of France). Comp Biochem Physiol B Biochem Mol Biol 125:359-369

Bouquet AL, Mille D, Blachier P, Oudot G and others (2011) Recherche de solutions zootechniques pour limiter les surmortalités-bilan des suivis 2010. Centre Régional d'Expérimentation et d'Application Aquacole, Le Château d'Oléron

Childress JJ, Somero GN (1979) Depth-related enzymic activities in muscle, brain and heart of deep-living pelagic marine teleosts. Mar Biol 52:273-283

Corporeau C, Groisillier A, Jeudy A, Barbeyron T and others (2011) A functional study of transforming growth factorbeta from the gonad of Pacific oyster Crassostrea gigas. Mar Biotechnol (NY) 13:971-980

Côté J, Himmelman JH, Claereboudt MR (1994) Separating effects of limited food and space on growth of the giant 
scallop Placopecten magellanicus in suspended culture. Mar Ecol Prog Ser 106:85-91

> De Decker S, Normand J, Saulnier D, Pernet F, Castagnet S, Boudry P (2011) Responses of diploid and triploid Pacific oysters Crassostrea gigas to Vibrio infection in relation to their reproductive status. J Invertebr Pathol 106:179-191

> Dégremont L (2011) Evidence of herpesvirus (OsHV-1) resistance in juvenile Crassostrea gigas selected for high resistance to the summer mortality phenomenon. Aquaculture 317:94-98

Dégremont L, Bédier E, Boudry P (2010a) Summer mortality of hatchery-produced Pacific oyster spat (Crassostrea gigas). II. Response to selection for survival and its influence on growth and yield. Aquaculture 299:21-29

> Dégremont L, Boudry P, Ropert M, Samain JF, Bédier E, Soletchnik P (2010b) Effects of age and environment on survival of summer mortality by two selected groups of the Pacific oyster Crassostrea gigas. Aquaculture 299: 44-50

> Delaporte M, Soudant P, Lambert C, Moal J, Pouvreau S, Samain JF (2006) Impact of food availability on energy storage and defense related hemocyte parameters of the Pacific oyster Crassostrea gigas during an experimental reproductive cycle. Aquaculture 254:571-582

> DuBois M, Gilles KA, Hamilton JK, Rebers PA, Smith F (1956) Colorimetric method for determination of sugars and related substances. Anal Chem 28:350-356

$>$ Floreto EAT, Bayer R, Brown PB (2000) The effect of soybean-based diets, with and without amino-acid supplementation, on growth and biochemical composition of juvenile American lobster, Homarus americanus. Aquaculture 189:211-235

> Flye-Sainte-Marie J, Pouvreau S, Paillard C, Jean F (2007) Impact of brown ring disease on the energy budget of the Manila clam Ruditapes philippinarum. J Exp Mar Biol Ecol 349:378-389

Folch J, Lees M, Sloane-Stanlez GH (1957) A simple method for the isolation and purification of total lipids from animal tissues. J Biol Chem 226:497-509

Forrest BM, Keeley NB, Hopkins GA, Webb SC, Clement DM (2009) Bivalve aquaculture in estuaries: review and synthesis of oyster cultivation effects. Aquaculture 298: $1-15$

Fréchette M, Butman CA, Geyer WR (1989) The importance of boundary-layer flows in supplying phytoplankton to the benthic suspension feeder, Mytilus edulis L. Limnol Oceanogr 34:19-36

Gagnaire B, Soletchnik P, Madec P, Geairon P, Le Moine O, Renault T (2006) Diploid and triploid Pacific oysters, Crassostrea gigas (Thunberg), reared at two heights above sediment in Marennes-Oleron Basin, France: difference in mortality, sexual maturation and hemocyte parameters. Aquaculture 254:606-616

Gangnery A, Chabirand J-M, Lagarde F, Gall PL, Oheix J, Bacher C, Buestel D (2003) Growth model of the Pacific oyster, Crassostrea gigas, cultured in Thau Lagoon (Méditerranée, France). Aquaculture 215:267-290

- Garnier M, Labreuche Y, Garcia C, Robert A, Nicolas JL (2007) Evidence for the involvement of pathogenic bacteria in summer mortalities of the Pacific oyster Crassostrea gigas. Microb Ecol 53:187-196

Gay M, Renault T, Pons AM, Le Roux F (2004) Two Vibrio splendidus related strains collaborate to kill Crassostrea gigas: taxonomy and host alterations. Dis Aquat Org 62:65-74
Genard B, Pernet F, Lemarchand K, Boudry P, Moraga D, Tremblay R (2011) Physiological and biochemical changes associated with massive mortality event occurring during premetamorphic development of American oyster Crassostrea virginica. Aquat Living Resour 24:247-260

Greenway SC, Storey KB (1999) The effect of prolonged anoxia on enzyme activities in oysters (Crassostrea virginica) at different seasons. J Exp Mar Biol Ecol 242: 259-272

> Gustafson LL, Ellis SK, Beattie MJ, Chang BD and others (2007) Hydrographics and the timing of infectious salmon anemia outbreaks among Atlantic salmon (Salmo salar L.) farms in the Quoddy region of Maine, USA and New Brunswick, Canada. Prev Vet Med 78:35-56

> Harvell CD, Kim K, Burkholder JM, Colwell RR and others (1999) Emerging marine diseases-climate links and anthropogenic factors. Science 285:1505-1510

- Harvell CD, Mitchell CE, Ward JR, Altizer S, Dobson AP, Ostfeld RS, Samuel MD (2002) Climate warming and disease risks for terrestrial and marine biota. Science 296:2158-2162

> Holliday JE, Maguire GB, Nell JA (1991) Optimum stocking density for nursery culture of Sydney rock oysters (Saccostrea commercialis). Aquaculture 96:7-16

$>$ Hurlbert SH (1984) Pseudoreplication and the design of ecological field experiments. Ecol Monogr 54:187-211

> Kristoffersen AB, Viljugrein H, Kongtorp RT, Brun E, Jansen PA (2009) Risk factors for pancreas disease (PD) outbreaks in farmed Atlantic salmon and rainbow trout in Norway during 2003-2007. Prev Vet Med 90: $127-136$

Krkošek M (2010) Host density thresholds and disease control for fisheries and aquaculture. Aquacult Environ Interact 1:21-32

> Lafferty KD, Porter JW, Ford SE (2004) Are diseases increasing in the ocean? Annu Rev Ecol Evol Syst 35:31-54

Laing I (2009) Oysters-shellfish farming. In: John HS, Karl KT, Steve AT (eds) Encyclopedia of ocean sciences, 2nd edn. Academic Press, Oxford, p 274-286

> Le Deuff RM, Renault T, Gérard A (1996) Effects of temperature on herpes-like virus detection among hatcheryreared larval Pacific oyster Crassostrea gigas. Dis Aquat Org 24:149-157

Lightner DV (2011) Virus diseases of farmed shrimp in the Western Hemisphere (the Americas): a review. J Invertebr Pathol 106:110-130

Lynch SA, Carlsson J, Culloty SC (2011) Investigation into the involvement of ostreid herpes virus 1 (OsHV-1) in summer mortalities of pacific oyster, Crassostrea gigas, spat and market sized adults in Ireland. J Shellfish Res 30:528-529

Maguire JA, Burnell GM (2001) The effect of stocking density in suspended culture on growth and carbohydrate content of the adductor muscle in two populations of the scallop (Pecten maximus L.) in Bantry Bay, Ireland. Aquaculture 198:95-108

> Martenot C, Oden E, Travaillé E, Malas JP, Houssin M (2011) Detection of different variants of ostreid herpesvirus 1 in the Pacific oyster, Crassostrea gigas between 2008 and 2010. Virus Res 160:25-31

> Mazón-Suástegui JM, Ruíz-Ruíz KM, Parres-Haro A, Saucedo PE (2008) Combined effects of diet and stocking density on growth and biochemical composition of spat of the Cortez oyster Crassostrea corteziensis at the hatchery. Aquaculture 284:98-105 
McCallum HI, Kuris A, Harvell CD, Lafferty KD, Smith GW, Porter J (2004) Does terrestrial epidemiology apply to marine systems? Trends Ecol Evol 19:585-591

Meyer E, Green A, Moore M, Manahan D (2007) Food availability and physiological state of sea urchin larvae (Strongylocentrotus purpuratus). Mar Biol 152:179-191

Montagnani C, Tirapé A, Boulo V, Escoubas JM (2005) The two Cg-timp mRNAs expressed in oyster hemocytes are generated by two gene families and differentially expressed during ontogenesis. Dev Comp Immunol 29: 831-839

Moran AL, Manahan DT (2004) Physiological recovery from prolonged 'starvation' in larvae of the Pacific oyster Crassostrea gigas. J Exp Mar Biol Ecol 306:17-36

$>$ Murray AG, Peeler EJ (2005) A framework for understanding the potential for emerging diseases in aquaculture. Prev Vet Med 67:223-235

> Mydlarz LD, Jones LE, Harvell CD (2006) Innate immunity environmental drivers and disease ecology of marine and freshwater invertebrates. Annu Rev Ecol Evol Syst 37: 251-288

> Nell JA (2002) Farming triploid oysters. Aquaculture 210: 69-88

Normand J, Le Pennec M, Boudry P (2008) Comparative histological study of gametogenesis in diploid and triploid Pacific oysters (Crassostrea gigas) reared in an estuarine farming site in France during the 2003 heatwave. Aquaculture 282:124-129

- Normand J, Ernande B, Haure J, McCombie H, Boudry P (2009) Reproductive effort and growth in Crassostrea gigas: comparison of young diploid and triploid oysters issued from natural crosses or chemical induction. Aquat Biol 7:229-241

Oberbeckmann S, Wichels A, Wiltshire KH, Gerdts G (2011) Occurrence of Vibrio parahaemolyticus and Vibrio alginolyticus in the German Bight over a seasonal cycle. Antonie van Leeuwenhoek 100:291-307

$>$ Oden E, Martenot C, Berthaux M, Travaillé E, Malas JP, Houssin M (2011) Quantification of ostreid herpesvirus 1 (OsHV-1) in Crassostrea gigas by real-time PCR: determination of a viral load threshold to prevent summer mortalities. Aquaculture 317:27-31

Parrish CC (1999) Determination of total lipid, lipid classes, and fatty acids in aquatic samples. In: Arts MT, Wainman BC (eds) Lipids in freshwater ecosystems. SpringerVerlag, New York, NY, p 5-20

Peeler EJ, Taylor NGH (2011) The application of epidemiology in aquatic animal health-opportunities and challenges. Vet Res 42:94

Pepin JF, Riou A, Renault T (2008) Rapid and sensitive detection of ostreid herpesvirus 1 in oyster samples by real-time PCR. J Virol Methods 149:269-276

$>$ Pernet F, Bricelj VM, Cartier S (2006) Lipid class dynamics during larval ontogeny of sea scallops, Placopecten magellanicus, in relation to metamorphic success and response to antibiotics. J Exp Mar Biol Ecol 329:265-280

Pernet F, Barret J, Marty C, Moal J, Le Gall P, Boudry P (2010) Environmental anomalies, energetic reserves and fatty acid modifications in oysters coincide with an exceptional mortality event. Mar Ecol Prog Ser 401: 129-146

Plana S, Sinquin G, Maes P, Paillard C, Le Pennec M (1996) Variations in biochemical composition of juvenile Ruditapes philippinarum infected by a Vibrio sp. Dis Aquat Org 24:205-213
Repamo (2009) Bilan 2009 du réseau Repamo. Rapport interne Ifremer. http://wwz.ifremer.fr/repamo/content/download/ 32431/445002/file/If_Rapport_REPAMO_2009.pdf Accessed December 202011

Repamo (2010) Bilan 2010 du réseau Repamo. Rapport interne Ifremer. wwz.ifremer.fr/repamo/content/download/45379/641129/file/IF_Rapport\%20REPAMO\%2020 10.pdf. Accessed December 20, 2011

Salama NKG, Murray AG (2011) Farm size as a factor in hydrodynamic transmission of pathogens in aquaculture fish production. Aquacult Environ Interact 2:61-74

Samain JF, McCombie H (2008) Summer mortality of Pacific oyster Crassostrea gigas: the Morest Project. Ifremer/ Quæ Editions, Versailles

Saulnier D, De Decker S, Haffner P (2009) Real-time PCR assay for rapid detection and quantification of Vibrio aestuarianus in oyster and seawater: a useful tool for epidemiologic studies. J Microbiol Methods 77:191-197

Saulnier D, De Decker S, Haffner P, Cobret L, Robert M, Garcia C (2010) A large-scale epidemiological study to identify bacteria pathogenic to Pacific oyster Crassostrea gigas and correlation between virulence and metalloprotease-like activity. Microb Ecol 59:787-798

Sauvage C, Pépin JF, Lapègue $S$, Boudry P, Renault T (2009) Ostreid herpes virus 1 infection in families of the Pacific oyster, Crassostrea gigas, during a summer mortality outbreak: differences in viral DNA detection and quantification using real-time PCR. Virus Res 142:181-187

Schikorski D, Faury N, Pépin JF, Saulnier D, Tourbiez D, Renault T (2011a) Experimental ostreid herpesvirus 1 infection of the Pacific oyster Crassostrea gigas: kinetics of virus DNA detection by q-PCR in seawater and in oyster samples. Virus Res 155:28-34

Schikorski D, Renault T, Saulnier D, Faury N, Moreau P, Pépin JF (2011b) Experimental infection of Pacific oyster Crassostrea gigas spat by ostreid herpesvirus 1: demonstration of oyster spat susceptibility. Vet Res 42:27

Segarra A, Pépin JF, Arzul I, Morga B, Faury N, Renault T (2010) Detection and description of a particular ostreid herpesvirus 1 genotype associated with massive mortality outbreaks of Pacific oysters, Crassostrea gigas, in France in 2008. Virus Res 153:92-99

Soletchnik P, Razet D, Geairon P, Faury N, Goulletquer P (1997) Ecophysiology of maturation and spawning in oyster (Crassostrea gigas): metabolic (respiration) and feeding (clearance and absorption rates) responses at different maturation stages. Aquat Living Resour 10:177-185

> Soletchnik P, Faury N, Goulletquer P (2006) Seasonal changes in carbohydrate metabolism and its relationship with summer mortality of Pacific oyster Crassostrea gigas (Thunberg) in Marennes-Oléron bay (France). Aquaculture 252:328-338

> Stuck KC, Overstreet RM (1994) Effect of Baculovirus penaei on growth and survival of experimentally infected postlarvae of the Pacific white shrimp, Penaeus vannamei. J Invertebr Pathol 64:18-25

Stuck KC, Stuck LM, Overstreet RM, Wang SY (1996) Relationship between BP (Baculovirus penaei) and energy reserves in larval and postlarval Pacific white shrimp Penaeus vannamei. Dis Aquat Org 24:191-198

> Taylor JJ, Rose RA, Southgate PC, Taylor CE (1997) Effects of stocking density on growth and survival of early juvenile silver-lip pearl oysters, Pinctada maxima (Jameson), held in suspended nursery culture. Aquaculture 153: $41-49$ 
Thompson JR, Randa MA, Marcelino LA, Tomita-Mitchell A, Lim E, Polz MF (2004) Diversity and dynamics of a North Atlantic coastal Vibrio community. Appl Environ Microbiol 70:4103-4110

Tirapé A, Bacque C, Brizard R, Vandenbulcke F, Boulo V (2007) Expression of immune-related genes in the oyster Crassostrea gigas during ontogenesis. Dev Comp Immunol 31:859-873

Editorial responsibility: Megan La Peyre,

Baton Rouge, Louisiana, USA
Viljugrein H, Staalstrøm A, Molvær J, Urke HA, Jansen PA (2009) Integration of hydrodynamics into a statistical model on the spread of pancreas disease (PD) in salmon farming. Dis Aquat Org 88:35-44

Webb SC, Fidler A, Renault T (2007) Primers for PCR-based detection of ostreid herpes virus-1 (OsHV-1): application in a survey of New Zealand molluscs. Aquaculture 272:126-139

Submitted: February 20, 2012; Accepted: April 30, 2012

Proofs received from author(s): June 15, 2012 